

\section{DISCLAIMER}

This report was prepared as an account of work sponsored by an agency of the United States Government. Neither the United States Government nor any agency Thereof, nor any of their employees, makes any warranty, express or implied, or assumes any legal liability or responsibility for the accuracy, completeness, or usefulness of any information, apparatus, product, or process disclosed, or represents that its use would not infringe privately owned rights. Reference herein to any specific commercial product, process, or service by trade name, trademark, manufacturer, or otherwise does not necessarily constitute or imply its endorsement, recommendation, or favoring by the United States Government or any agency thereof. The views and opinions of authors expressed herein do not necessarily state or reflect those of the United States Government or any agency thereof. 


\section{DISCLAIMER}

Portions of this document may be illegible in electronic image products. Images are produced from the best available original document. 
Reference to a company or product name does not imply approval or recommendation of the product by Union Carbide Corporation or the U.S. Energy Research and Development Administration to the exclusion of others that may meet specifications.

Printed in the United States of America. Available from National Technical Information Service

U.S. Department of Commerce

5285 Port Royal Road, Springfield, Virginia 22161

Price: Printed Copy \$4.00; Microfiche \$2.25

This report was prepared as an account of work sponsored by the United States Government. Neither the United States nor the Energy Research and Development Administration, nor any of their employees, nor any of their contractors, subcontractors, or their employees, makes any warranty, express or implied, or assumes any legal liability or responsibility for the accuracy, completeness or usefulness of any information, apparatus, product or process disclosed, or represents that its use would not infringe privately owned rights. 
Date of Issue: April 18, 1975

Report Number: Y-1969

Distribution Category: UC-4

\title{
FLUORINE MAGNETIC RESONANCE DETERMINATION OF WATER, ALCOHOLS, AND AMINES
}

\author{
J. G. Dorsey \\ M. H. Eager \\ A. C. Rutenberg \\ L. A. Green
}

Plant Laboratory Department

Y.12 Product Certification Division

\begin{abstract}
This report was prepared an account of work This report was prepared as an account of work sponsored by the United States Government. Neither the United States nor the United States Energy Research and Development Administration, nor any of subcontractors, or their employees, makes any warranty, express or implied, or assumes àny legal liahility or responsihility for the accuracy, completeness or usefulness of any information, apparat us, product or
or or usefulness of any information, apparatus, product or
process disclosed, or represents that its use would not infinge privately owned rights.
\end{abstract}

Oak Ridge Y-12 Plant

P. O. Box Y, Oak Ridge, Tennessee 37830

Prepared for the US Energy Research and Development Administration Undor US Government Contract W=7405-eng-2h 


\begin{abstract}
A fluorine magnetic resonance method to quantitatively and qualitatively determine labile hydrogen in water and in organic compounds has been investigated. This method involves the in situ reaction of the material of interest with hexafluoroacetone and a subsequent fluorine magnetic resonance analyșis of the resulting adducts and standarrss.
\end{abstract}




\section{CONTENTS}

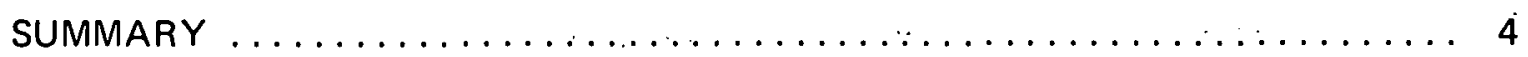

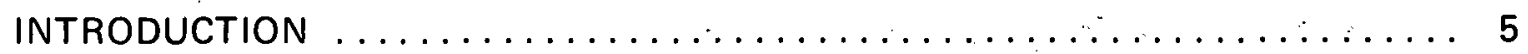

APPLICATION OF THE FLUORINE MAGNETIC RESONANCE METHOD $\ldots . \ldots 77$

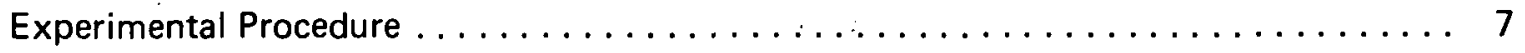

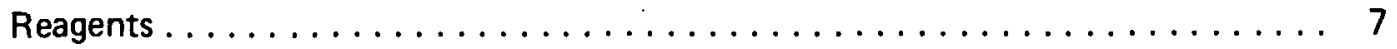

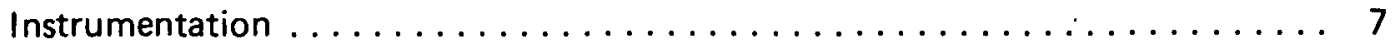

Preparation of Materials for Nuclear Magnetic Resonance Analysis . . . . . . . 7

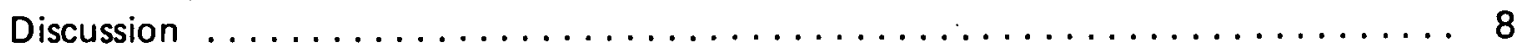

Conclusions $\ldots \ldots \ldots \ldots \ldots \ldots \ldots \ldots \ldots \ldots \ldots \ldots \ldots \ldots \ldots \ldots \ldots \ldots, 12$

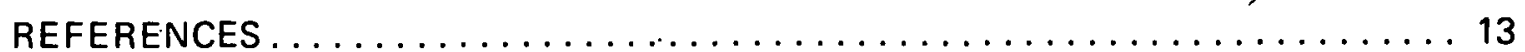

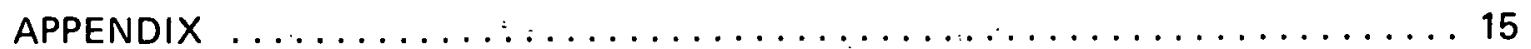

Spectra of Various Materials . . . . . . . . . . . . . . . . . . . . . . . 15 


\section{SUMMARY}

A rapid and sensitive fluorine magnetic resonance (FMR) method has been utilized to determine the water, hydroxyl, and amine content of a wide variety of organic materials including epoxy and urethane resin systems. Hexafluoroacetone reacts readily with small amounts of the labile hydrogen of organic materials to form adducts containing the probe, $\left.-\mathrm{CICF}_{3}\right)_{2} \mathrm{OH}$ :

$$
\left(\mathrm{CF}_{3}\right)_{2} \mathrm{C}=\mathrm{O}+\mathrm{RJH}_{\mathrm{n}} \rightarrow\left(\mathrm{CF}_{3}\right)_{2} \mathrm{C}(\mathrm{OH}) \mathrm{JH}_{\mathrm{n}-1} \mathrm{R}
$$

where:

\section{J represents oxygen, sulfur, or nitrogen.}

The increased sensitivity of the fluorine method over the normal proton nuclear magnetic resonance (NMR method) is apparent. For every molecule reacted, the adduct formed contains six fluorine atoms which give a single, sharp fluorine signal. Thus, an adequate signal for identification purposes can be obtained with only one to five milligrams of sample in 0.5 milliliters of solvent. Since fluorine chemical shifts are, in general, an order of magnitude larger than proton chemical shifts for á given structure, it is possible to distinguish between different alcohols, amines, and water. 


\section{INTRODUCTION}

The quantitation of water in organic materials has been of immense interest to researchers for a number of years. Moreover, the simultaneous estimation of the water and hydroxyl contents is of immediate interest to the Oak Ridge Y-12 Plant. (a) Many polymers, such as the polyethers, polyesters, polyamides, polyurethanes, epoxy resins, silicones; and formaldehyde resins contain labile hydrogen. This report will describe some of the analyses that are used for determining the water, amine, and hydroxyl contents in components of resin systems used in the $\mathrm{Y} \cdot 12$ Plant.

Determination of the water and hydroxyl contents by several analytical methods has been reviewed extensively. $(1-4)$ Proton magnetic resonance (PMR) has been employed rather unsuccessfully because the protons of hydroxyl $(-\mathrm{OH})$, amine $(-\mathrm{NH})$, and water generally exchange with sufficient rapidity to give a single, often broad peak. Therefore, measuring water in a material by PMR is complicated by the presence of other impurities under that peak.

Several investigators have tried to derivatize alcohols and observe the PMR spectrum of the prepared derivative. Babiec and coworkers $(5)$ have prepared the dichloroacetate esters of alcohols and examined the $-\mathrm{CHCL}_{2}$ peak by PMR. This method was only moderately successful since the chemical shifts between different alcohols were rather small.

A more successful approach was to utilize the fluorine magnetic resonance (FMR) method and fluorine derivatizing agents since fluorine chemical shifts are an order of magnitude greater than proton chemical shifts. Manatt $(6)$ ingeniously prepared the trifluoroacetate (TFA) esters of a large number of alcohols and studied their FMR spectra. In another article, Manatt and coworkers (7) characterized the hydroxyl groups in poly-(propylene oxides), while Voelter, et al(8) have studied the FMR spectra of the TFA derivatives of steroids.

In 1970, Leader(9) first reported a hexafluoroacetone (HFA) method to characterize alcohols. There are several advantages of the Leader in situ method over the Manatt procedure. The Leader method eliminates the preliminary preparation of a derivative of the alcohol in a separate operation. By using HFA, a FMR signal corresponding to six fluorine atoms per active hydrogen atom is obtained, compared with only three fluorine atoms when the TFA is prepared by the Manatt procedure. In general, the chemical shifts of the HFA adducts of certain alcohols are substantially larger than the corresponding differences in the TFA esters. The chemical shifts relative to $\mathrm{HFA}\left(\mathrm{H}_{2} \mathrm{O}\right)$ for a number of alcohols, glycols, and amines have been tabulated by Leader. $(10)$ Ho $(11,12)$ has applied the HFA technique and FMR to the quantitative measurement of the hydroxyl groups in polymers and to the characterization and quantitation of phenols.

(a) Operated by the Union Carbide Corporation's Nuclear Division for the US Energy Research and Development Administration. 
In the work described here, the HFA technique was used to study the epoxy resins, amines, urethanes, and alcohols used in the Y-12 Plant. Not only have water estimates been obtained, but also the hydroxyl numbers for several epoxy resins. The results compare quite well with data obtained on these materials by the Karl Fischer method and were in agreement with the literature values on similar formulations. 


\section{APPLICATION OF THE FLUORINE MAGNETIC RESONANCE METHOD}

\section{EXPERIMENTAL PROCEDURE}

\section{Reagents}

The hexafluoroacetone (HFA) as well as the n-butyltrifluoroacetate (NBTFA) used in this study were supplied by PCR, Incorporated, Gainesville, Florida. The hydrolysis products (trifluoroacetic acid and butanol), present in the as-received NBTFA, necessitate the application of fractional distillation. Ethyl trifluoroacetate was obtained from Pfaltz and Bauer, Flushing, New York. The solvents used were generally from freshly opened reagent-grade bottles. The ethyl acetate contained considerable water and ethanol, both of which can be removed by passing the solvent through an alumina column. (13)

\section{Instrumentation}

The FMR spectra were obtained using a Bruker HFX-15 NMR spectrometer (probe temperature, $25^{\circ} \mathrm{C}$ ). The fluorine-observing frequency is $84.67 \mathrm{MHz}$ at a field of 21,140 gauss. The fluorine resonance of hexafluorobenzene was the internal lock signal.

\section{Preparation of Materials for Nuclear Magnetic Resonance Analysis}

The hexafluoroacetone adducts were prepared in two ways:

1. A stock solution was prepared by bubbling the gaseous HFA through the solvent chilled in an ice bath. The material to be analyzed was weighed into a 5-millimeter NMR tube and 0.5 milliliter of the stock solution was added. Hexafluorobenzene was used as the lock material.

2. The sample and standard were weighed into a two-milliliter vial. Approximately 0.5 milliliter of an appropriate solvent was added and HFA was bubbled into the vial for 30 to 180 seconds, depending upon the amount of sample used. The HFA addition was carried out in a glove box at $10 \%$ relative humidity. The solution was transferred.to an NMR tube in the glove box and hexafluorobenzene added as the lock material.

The first procedure is more easily adapted to water analysis; however, quite often more HFA was required for the complete reaction of all components in the resin systems than was dissolved in the ethyl acetate by the first procedure. Therefore, the second procedure was used in the major portion of this work.

The weight of sample for HFA analysis is dependent upon the type of analysis required; ie, water analysis or characterization. The chemical shifts depend upon the solvents and the weight of sample used. The HFA chemical shift especially varies from solvent to solvent. Caution should be used in identifying the proper peak as the standard peak, since the position of unreacted HFA is sometimes upfield and sometimes downfield from the NBTFA, depending upon the solvent used. It is imperative that there be unreacted HFA present to trisure coimplete reaction of the sample. 


\section{DISCUSSION}

A wide variety of materials have been analyzed by the FMR method. In this report only a few spectra will be discussed which serve as examples of the utility of the method. A list of chemical shifts relative to internal hexafluorobenzene of the materials investigated in this work is presented in Table 1.

To determine the reliability of the method, an experiment was devised to weigh approximately equal amounts of 1,3-propanediol, 1,4-butanediol, and a standard [such as n-butyltrifluoroacetate (NBTFA)], react the alcohols with HFA, and compare the experimental values obtained with the theoretical values. Spectra of the various materials are presented in the Appendix.

In Figure A-1, a spectrum of 1,3-propanediol is given: Peak $A$ is unreacted $\mathrm{H} F \bar{A}$, while Peak $B$ represents the fluorine in 0.1857 gram of NBTFA. Peak $C$ is the 1,3-propanediol-HFA adduct prepared with 0.28485 gram of 1,3-propanediol. Peak $D$ is the water-HFA adduct.

Table 1

CHEMICAL SHIFTS OF MATERIALS STUDIED

\begin{tabular}{|c|c|c|}
\hline Material & Solvent & $\begin{array}{l}\text { Chemical Shift }{ }^{(1)} \\
(\mathrm{Hz})\end{array}$ \\
\hline 1.4-Butaneḍiol & Carbon Tetrachloride & 6998 \\
\hline Polybutylene Ether Glycol & Carbon Tetrachloride & 6977 \\
\hline Phenylglycidyl Ether & Ethyl Acetate & 7080 \\
\hline Epi-Rez 508 & Ethyl Acetate & 6990 \\
\hline Epon 828 & Ethyl Acetate & 6990 \\
\hline Epon 1001 & Ethyl Acetate & 7025 \\
\hline $\begin{array}{l}\text { Dynachom } \\
\text { 2-Aminoethanol }\end{array}$ & Ethyl Acetate & 7007 \\
\hline NH Adduct & Ethyl Acetate & 7180 \\
\hline OH Adduct & Ethyl Acetate & 7065 \\
\hline Ethylenediamine & Ethyl Acetate & 7178 \\
\hline Ethylene Glycol & Ethyl Acetate & 7072 \\
\hline $\begin{array}{l}\text { Apogen } \\
\text { BHED }^{(2)}\end{array}$ & Ethyl Acctote & 7114 \\
\hline UH Adduct 1 & Benzene & 7000 \\
\hline $\mathrm{OH}$ Adduct 2 & Benzene & 7026 \\
\hline Methylenedianiline & Ethyl Acetate & 7180 \\
\hline Triethanolamine & Cthyl Acelale & $7000^{\circ}$ \\
\hline \multicolumn{3}{|l|}{ Diethanolamine } \\
\hline Adduct 1 & Ethyl Acetate & 7050 \\
\hline Maduiuct : & Ethyl Acetate & 7080 \\
\hline Adduct 3 & Ethyl Acetate & 7090 \\
\hline Adduct 4 & Ethyl Acetate & 7100 \\
\hline Adduct 5 & Ethyl Acetate & 7105 \\
\hline $\operatorname{MOCA}(3)$ & Ethyl Acetate & 7108 \\
\hline 1,3-Propanediol & Ethyl Acetate & 7092 \\
\hline 1,4-Butanedlol & Ethyl Acetate & $\% 102$ \\
\hline \multicolumn{3}{|c|}{$\begin{array}{l}\text { (1) The shifts are all downfield from the internal lock material, } \mathrm{C}_{6} \mathrm{~F}_{6} \text {, } \\
\text { dissolved in the solutions. The fluorine frequency is } 84.67 \mathrm{MHz} \text { at } \\
21,140 \text { gauss. }\end{array}$} \\
\hline (2) Bishydroxyethyldimera & & \\
\hline
\end{tabular}


From the integrals, the milliequivalents of 1,3-propanediol in the sample can be calculated using the following formula:

$$
\frac{W_{k}(I \mu / F \mu)}{M W_{k}\left(I_{k} / F_{k}\right)(S)} \times 1000=\text { meq } O H / g,
$$

where:

$$
\begin{aligned}
& W_{k} \text { represents the weight of the standard, in grams; } \\
& \text { I } \mu \text { the integral of the standard; } \\
& \mathrm{MW}_{\mathrm{k}} \text { the molecular weight of standard; } \\
& \text { I } \mu \text { the sum of the integrals for all } \mathrm{OH} \text { adducts in the unknown; } \\
& \text { S the weight of the sample, in grams; } \\
& \mathrm{F} \mu \quad \text { the number of fluorine atoms in the sample-adduct group (always 6), and } \\
& \mathrm{F}_{\mathrm{k}} \text { the number of fluorine atoms in the group used as the standard (ie, } \mathrm{CF}_{3}=
\end{aligned}
$$

The NBTFA $\left(\mathrm{CH}_{3} \mathrm{CH}_{2} \mathrm{CH}_{2} \mathrm{CH}_{2} \mathrm{OCCF}_{3}\right)$ has a molecular weight of 170.1 and contains three equivalent fluorine atoms per molecule. Each HFA adduct contains six fluorine atoms. From the integrals, the propanediol calculates to $27.04 \mathrm{meq} / \mathrm{g}$, compared to a theoretical value of $26.28 \mathrm{meq} / \mathrm{g}$. Note that the propanediol is quite wet, containing $2.5 \mathrm{wt} \%$ water.

In Figure $A-2$, the spectrum of 1,4-butanediol is given. Peaks $A, B$, and $D$ are the same as those described in Figure A-1. Peak $C$ is the HFA adduct of 1,4-butanediol and is located 10 $\mathrm{Hz}$ downfield from the 1,3-propanediol-HFA adduct. Experimentally, a value of 23.21 $\mathrm{meq} / \mathrm{g}$ is calculated for the 1,4-butanediol compared to a theoretical value of $22.19 \mathrm{meq} / \mathrm{g}$. The butanediol contains 2.2 wt \% water.

In Figure A-3, an FMR spectrum of 0.1506 gram of 1,3-propanediol, 0.1535 gram of 1,4-butanediol, and 0.1976 gram of NBTFA is shown. The 1,3-propanediol calculates to be $27.00 \mathrm{meq} / \mathrm{g}$ compared to a theoretical value of $26.3 \mathrm{meq} / \mathrm{g}$, and the 1,4-butanediol calculates to $22.45 \mathrm{meq} / \mathrm{g}$ experimentally versus $22.19 \mathrm{meq} / \mathrm{g}$ for the theoretical value.

The analysis of 4,4'-methylenebis(2-chloroaniline), commonly called MOCA, has been of great interest in $Y-12$ since OSHA placed the material in its list of 14 materials that are allegedly carcinogenic to man. The FMR spectrum of the HFA adduct of MOCA is provided in Figure A-4. The absorption at Peak $C$ is the HFA adduct of MOCA. The molecular weight of MOCA:<smiles>Nc1ccc(Cc2ccc(N)c(Cl)c2)cc1Cl</smiles> 
is 267.16. Since each MOCA molecule contains four labile hydrogens attached to nitrogen, its equivalent weight is $267.16 / 4$, or $66.79 \mathrm{~g} / \mathrm{eq}$, or $14.97 \mathrm{meq} / \mathrm{g}$. If the formula for MOCA is employed to calculate an experimental meq/g, a value of $7.73 \mathrm{meq} / \mathrm{g}$ is obtained which is approximately half of the theoretical value. Therefore, it is assumed that the HFA reacts with only one hydrogen on each nitrogen. Steric hindrance prohibits the other hydrogen from reacting.

Figure $\mathrm{A}-5$ is a spectrum of reagent-grade triethanolamine, $\mathrm{N}\left(\mathrm{CH}_{2} \mathrm{CH}_{2} \mathrm{OH}\right)_{3}$. The HFA adduct shows the material to be impure since only one $\mathrm{OH}$ adduct peak is expected in the spectrum. Figure $A-6$ is a spectrum of reagent-grade diethanolamine, $\mathrm{HN}\left(\mathrm{CH}_{2} \mathrm{CH}_{2} \mathrm{OH}\right)_{2}$. Note that the two spectra are quite different. Figure A-7 is the FMR spectrum of a mixture of 60.2 milligrams of triethanolamine (TEA) and 83.4 milligrams of diethanolamine (DEA). The proton spectra of these three samples would be essentially identical and of little use for identification purposes.

The FMR spectrum of $\underline{p}, \underline{p}^{\prime}$-methylenedianiline (MDA):

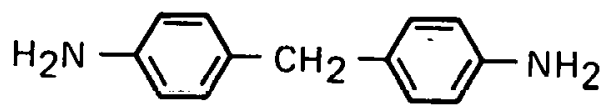

is shown in Figure A-8. As in MOCA, the calculated $\mathrm{meq} / \mathrm{g}$ is approximately half the theoretical, again showing that only one mole of HF.A reacts with a mole of primary amine.

The FMR spectrum, depicted in Figure A-9, is that of bishydroxyethyldimerate (BHED) whose chemical structure is:

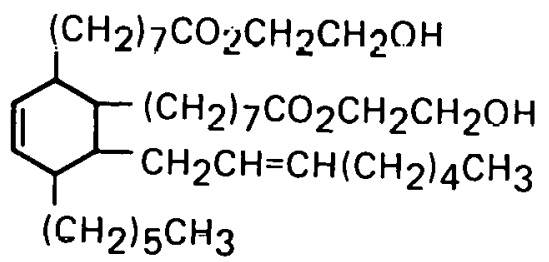

Note that there are two hydroxy groups in the spectrum. The proton magnetic resonance spectrum (Figure A-10) shows that the structure is not as shown by the vendor since there is a deficiency of unsaturated hydrogen. The fluorine spectrum indicates that there must be another alcohol in the material, possibly ethylene glycol. The calculated meq $\mathrm{OH} / \mathrm{g}$ is 1.0 $\mathrm{meq} / \mathrm{g}$ for the upfield peak and $1.3 \mathrm{meq} / \mathrm{g}$ for the downfield peak, or a total of $2.3 \mathrm{meq} / \mathrm{g}$. The FMR number was verified by acetylation of BHED which gave a value of 2.39 meq $\mathrm{OH} / \mathrm{g} .(14)$ The water content of BHED calculated from two FMR spectra averaged $0.205 \%$. Karl Fischer analysis gave $0.21 \%$ water. (14)

Apogen 141, which is a hydroxymethylated epoxy resin (Figure A-11), gave a broad FMR spectrum, indicating a complex resin with many different hydroxy groups. The material contains $3.1 \mathrm{meq} \mathrm{OH} / \mathrm{g}$ and $0.36 \%$ water. 
The purities of ethylene glycol (Figure A-12), ethylenediamine (Figure A-13) and 2-aminoethanol (Figure A-14) were checked by. the HFA reaction and subsequent FMR analysis. The ethylene glycol was the purest of the three. The ethylenediamine contained $12 \%$ of a hydroxyl-containing impurity while the 2 -aminoethanol contained $16 \%$ impurity. The water in the materials ranged from 1 to $21 / 2 \%$.

In Figure A-15, the FMR spectrum of Dynachem (Hystl C/NO 22, Type G-1000) is seen. The hydroxy-terminated resin contains $1.27 \mathrm{meq} \mathrm{OH} / \mathrm{g}$. The vendor estimated the hydroxyl content to be $1.18 \mathrm{meq} / \mathrm{g}$. However, in using the resin, the cure time and soft product indicates a higher hydroxyl content than that proposed by the vendor.

Some components in epoxy systems investigated using the HFA technique were Epon 1001, Epon 828, Epi-Rez 508, phenylglicidyl ether, and 1,2,7,8-diepoxyoctane. The epoxy equivalent weights of Epon 828, Epon 1001, and Epi-Rez 508 are 185 - 192, 450 - 550, and 171 - 177, respectively. (15) The hydroxyl values for materials whose epoxy equivalent weights are 174.5, 191.6, and 505 are $0.16,0.56$, and $2.73 \mathrm{meq} / \mathrm{g} .{ }^{(16)}$ No hydroxyl values could be obtained by the acetylation method employed on the BHED because epoxy groups react with acetic anhydride. However, the numbers obtained by the HFA procedure agree quite well with Lee and Neville. (15) Epon 1001 (Figures A-16 and A-17) calculates to 2.9 meq $\mathrm{OH} / \mathrm{g}$. Note the presence of a primary alcohol-HFA adduct in the spectrum downfield from the Epon 1001-HFA adduct resonance. Epon 828 (Figures A-18 and A-19) calculates to $0.57 \mathrm{meq} O H / \mathrm{g}$, while Epi-Rez 508 (Figures A-20 and A-21) calculates to 0.12 meq $\mathrm{OH} / \mathrm{g}$. Table 2 provides a list of the hydroxyl values for the three epoxy resins analyzed by FMR and other methods. (17) The FMR spectra (Figures A-22 and A-23) of 1,2,7,8-diepoxyoctane:

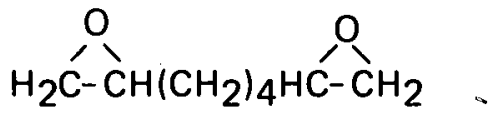

and phenylglycidyl ether:

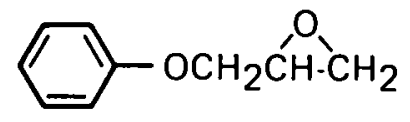

show that there is a little hydroxyl impurity in the phenylglycidyl ether.

The FMR method can also be used to monitor moisture in solids if the water can be quantitatively transferred to a suitable solvent and a blank obtained for the starting solvent. The toluene-water azeotrope from a solid was analyzed for moisture and contained 180 ppm. Gas chromatographic analysis of the toluene azeotrope gave $130 \mathrm{ppm}$ ( 18 )

Uralite $3121 \mathrm{~S}$ presents a good example of the utility of the FMR method. The PMR spectrum (Figure A-24) shows that Uralite is comprised of 1,4-butanediol and polybutylene ether glycol; the FMR spectrum (Figure A-25) of the HFA adducts shows that the 1,4-butanediol-HFA adduct resonance is $20 \mathrm{~Hz}$.downfield from the polybutylene ether glycol-HFA resonance. The total $\mathrm{meq} \mathrm{OH} / \mathrm{g}$ for the mix is $7.91 \mathrm{meq} / \mathrm{g}$, or an equivalent weight of 126.4. (The vendor estimates an equivalent weight of 126.) The vendor also estimated the material to contain 72 wt \% polybutylene ether glycol. The FMR spectrum 
Table 2

COMPARISON OF THE HYDROXYL VALUES OF SEVERAL EPOXY RESINS

(All Values in meq $\mathrm{OH} / \mathrm{g}$ )

\begin{tabular}{|c|c|c|c|c|c|}
\hline Resin (1) & $\begin{array}{c}\text { FMR } \\
\text { Method }\end{array}$ & Infrared $1(2)$ & Infrared $2^{(3)}$ & $\mathrm{GPC}^{(3)}$ & Acetylation (4) \\
\hline Epi-Rez 508 & 0.12 & 0.16 & & & 0.67 \\
\hline Epon 828 & 0.57 & 0.56 & 0.46 & 0.36 & 0.28 \\
\hline Epon 1001 & 2.90 & 2.73 & 3.02 & 2.43 & 2.39 \\
\hline $\begin{array}{l}\text { (1) Some vari } \\
\text { (2) From Han } \\
\text { (3) From Gel } \\
\text { (4) Frum Gre }\end{array}$ & $\begin{array}{l}n \text { between } \\
\text { ok of Eoo } \\
\text { neation C } \\
11)\end{array}$ & $\begin{array}{l}\text { erent batches is } \\
\text { iesins. (16) } \\
\text { latography. (i7) }\end{array}$ & expected. & & \\
\hline
\end{tabular}

can be used to verify the amount of polymer and also the equivalent weight of polybutylene ether glycol using the equation:

$$
I_{1}\left(E W_{1}\right)+I_{2}\left(E W_{2}\right)=I_{\tau}(E W A),
$$

where:
$I_{1}$ represents the integral of 1,4-butanediol,
$I_{2}$ the integral of polybutylene ether glycol,
EW 1 the equivalent weight of 1,4-butanediol,
[W.2 the equivalent weight of polybutylene glycol,
$I_{\tau} \quad$ the total integral, and
EW $_{\mathrm{A}}$ the average equivalent weight of the mix.

The equivalent weight of polybutylene ether glycol can be used to calculate the weight percent polybutylene ether glycol which was calculated to be $75 \%$.

\section{CONCLUSIONS}

The reaction of labile hydrogen with hexafluoroacetone and subsequent FMR analysis has shown real utility as an analytical method. The HFA method was found to be especially useful for determining water in alcohols and amines since ketones and amines interfere with the Karl Fischer analysis. The HFA-FMR hydroxy values of epoxy resins are more accurate numbers than those generated by the acetylation procedure since an epoxy group reacts to a certain extent with acetic anhydride. Probably the most important advantage of the method is that so much information can be gained from one simple analysis. 


\section{REFERENCES}

(1) The Chemistry of the Hydroxyl Groups, S. Patai, Editor; Interscience Publishers, New York, New York (1971):

(2) Geary, P. J.; Measurement of Moisture in Solids, SIRA Institute, Chislehurst, Kent (1970).

(3) Harris, C.; Talanta Rev, 19, p 1523 (1973).

(4) Veibel, Stig; The Determination of Hydroxy/ Groups; Academic Press, London (1972).

(5) Babiec, J. S., Barrante, J. R., and Vickers, G. D.; Analytical Chemistry, 40, p 610 (1968).

(6) Manatt, S. L.; J Am Chem Soc, 88, p 1323 (1966).

(7) Manatt, S. L., et al; Analytical Chemistry, 38, p 1063 (1966).

(8) Voelter, W., Breitmaier, E., Jung, G., and Bayer, E.; Org Mag Res, 2, p 251 (1970).

(9) Leader, Gordon R.; Analytical Chemistry, 42, p 16 (1970).

(10) Leader, Gordon R.; Analytical Chemistry, 45, p 1700 (1973).

(11) Ho, Floyd F. L.; Analytical Chemistry, 45, p 603 (1973).

(12) Ho, Floyd F. L.; Analytical Chemistry, 46, p 496 (1974).

(13) Ho, Floyd F. L.: Analytical Chemistry, 45, p 603 (1973).

(14) Green, L.; Written Communication.

(15) Handbook of Epoxy Resins, Henry Lee and Kris Neville, Editors, pp 4 - 66 and 4 -63; McGraw-Hill, Inc, New York, New York (1.967).

(16) Ibid; p 4 - 25.

(17) Gel Permeation Chromatography; Seminar Proceedings of Sixth International Seminar, Miami, Florida, October 7 - 9, 1968.

(18) Heatherly, J. L.; Written Communication. 


\section{THIS PAGE}

\section{WAS INTENTIONALLY \\ LEFT BLANK}




\section{APPENDIX}

\section{SPECTRA OF.VARIOUS MATERIALS}

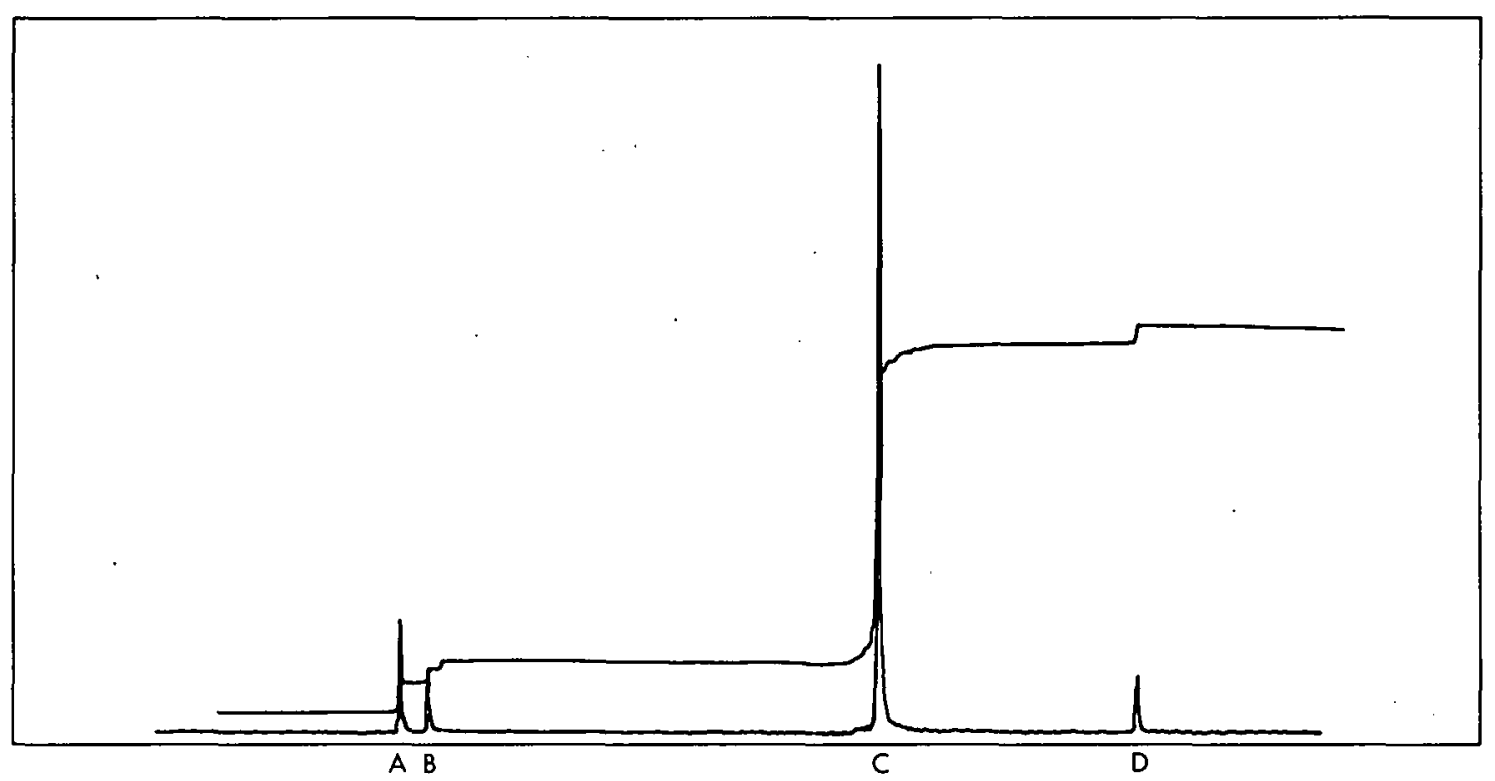

Figure A-1. FLUORINE MAGNETIC RESONANCE SPECTRUM OF 1,3-PROPANEDIOL. (Resonance at $A$ is Unreacted Hexafluoroacetone; Resonance B is 0.185 Gram of Standard, $\underline{n}$-Butyltrifluoroacetate; Resonance $C$ is 1,3-Propanediol-HFA Adduct Prepared Using 0.2848 Gram of 1,3-Propanediol; the Internal Lock is Hexafluorobenzene, and 0.5 Milliliter of Ethyl Acetate Served as a Solvent; Sweep Width $-20 \mathrm{~Hz} / \mathrm{cm}$, Offset $-6600 \mathrm{~Hz}$ )

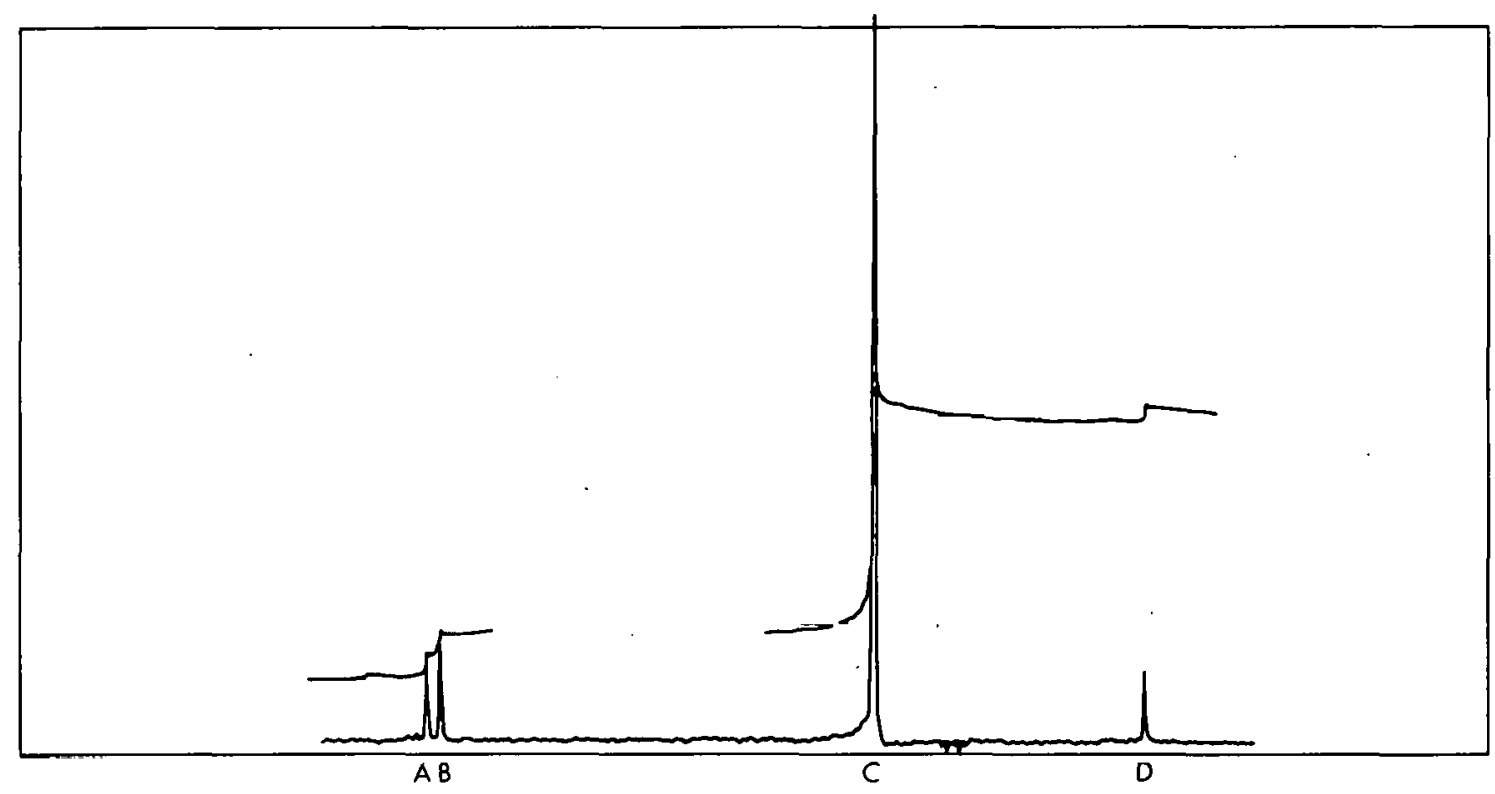

Figure A-2. FLUORINE MAGNETIC RESONANCE SPECTRUM OF 1,4-BUTANEDIOL. ITo 0.273 Gram of 1,4-Butanediol and 0.219 Gram of n-Butyltrifluoroacetate was Added 1 Milliliter of $5 \%$ Hexafluoroacetone in Ethyl Acetate; Sweep Width - $20 \mathrm{~Hz} / \mathrm{cm}$, Offset $-6600 \mathrm{~Hz}$ ) 


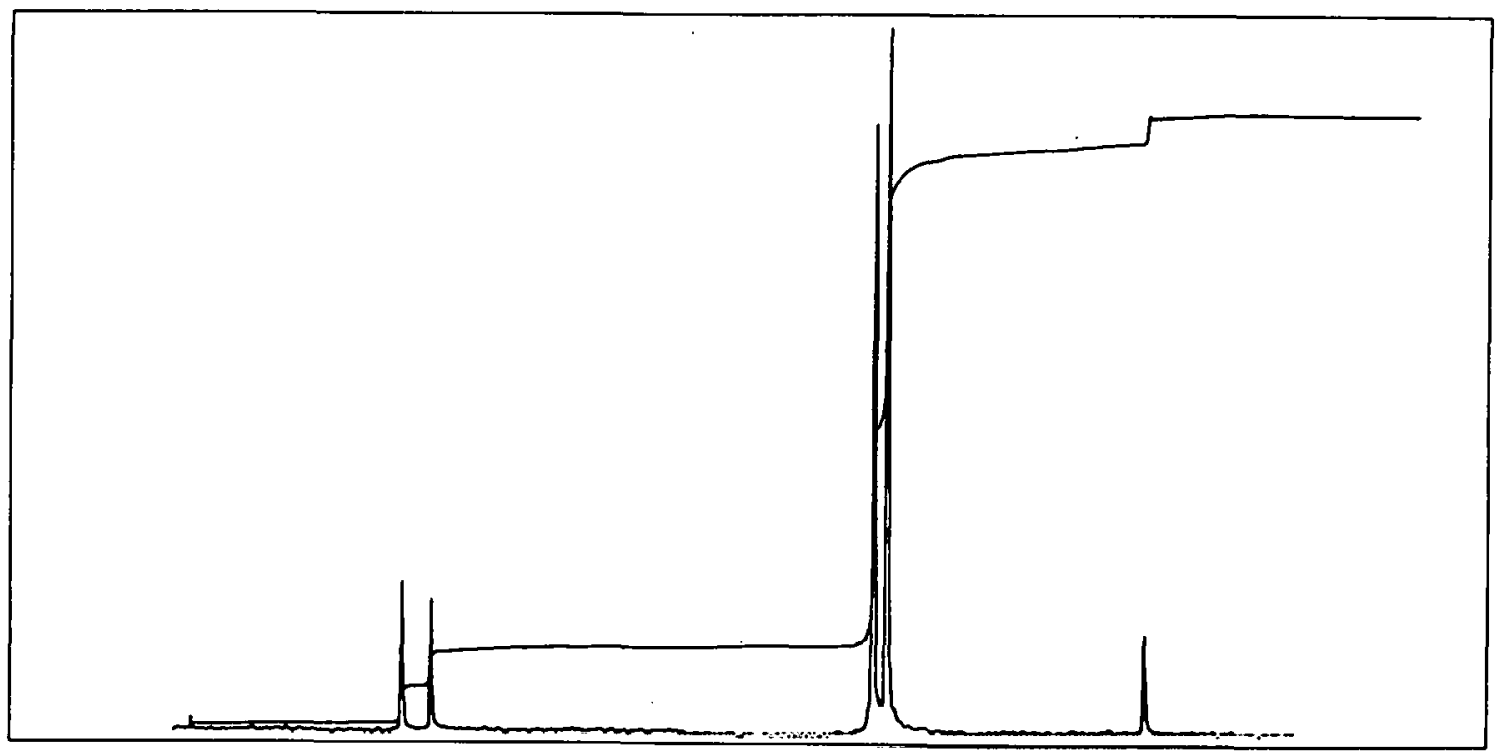

Figure A-3. FLUORINE MAGNETIC RESONANCE SPECTRUM OF A MIXTURE OF 0.1506 GRAM OF 1,3-PROPANEDIOL, 0.153 GRAM OF 1,4-BUTANEDIOL, AND 0.1976 GRAM OF n-BUTYLTRIFLUOROACETATE REACTED WITH EXCESS HEXAFLUOROACETONE IN ETHYL ACETATE. (Sweep Width - $20 \mathrm{~Hz} / \mathrm{cm}, 0 \mathrm{ffset} \cdot 6600$ $\mathrm{Hz})$

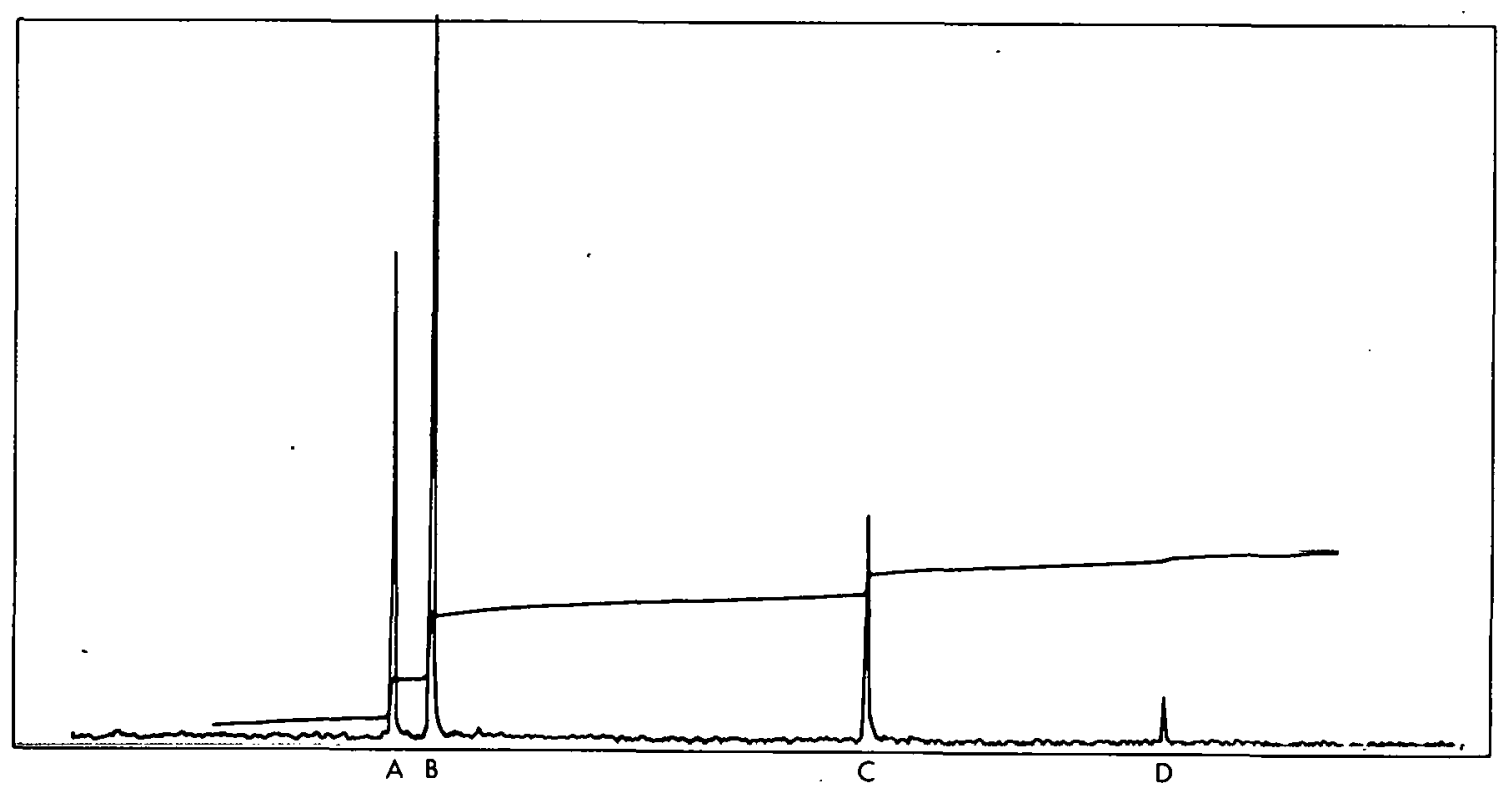

Figure A-4. FLUORINE MAGNETIC RESONANCE SPECTRUM OF 26.5 MILLIGRAMS OF 4,4-METHYLENEBIS (2-CHLOROANILINE) IN 5\% HEXAFLUOROACETONE IN ETHYL ACETATE SOLUTION. (The Solution Contains 220 Milligrams of n-Butyltrifluoroacetate and $5 \%$ Hexafluorobenzene as a Reference; Sweep Width $\cdot 20 \mathrm{~Hz} / \mathrm{cm}$, Offset $-6600 \mathrm{~Hz}$ ) 


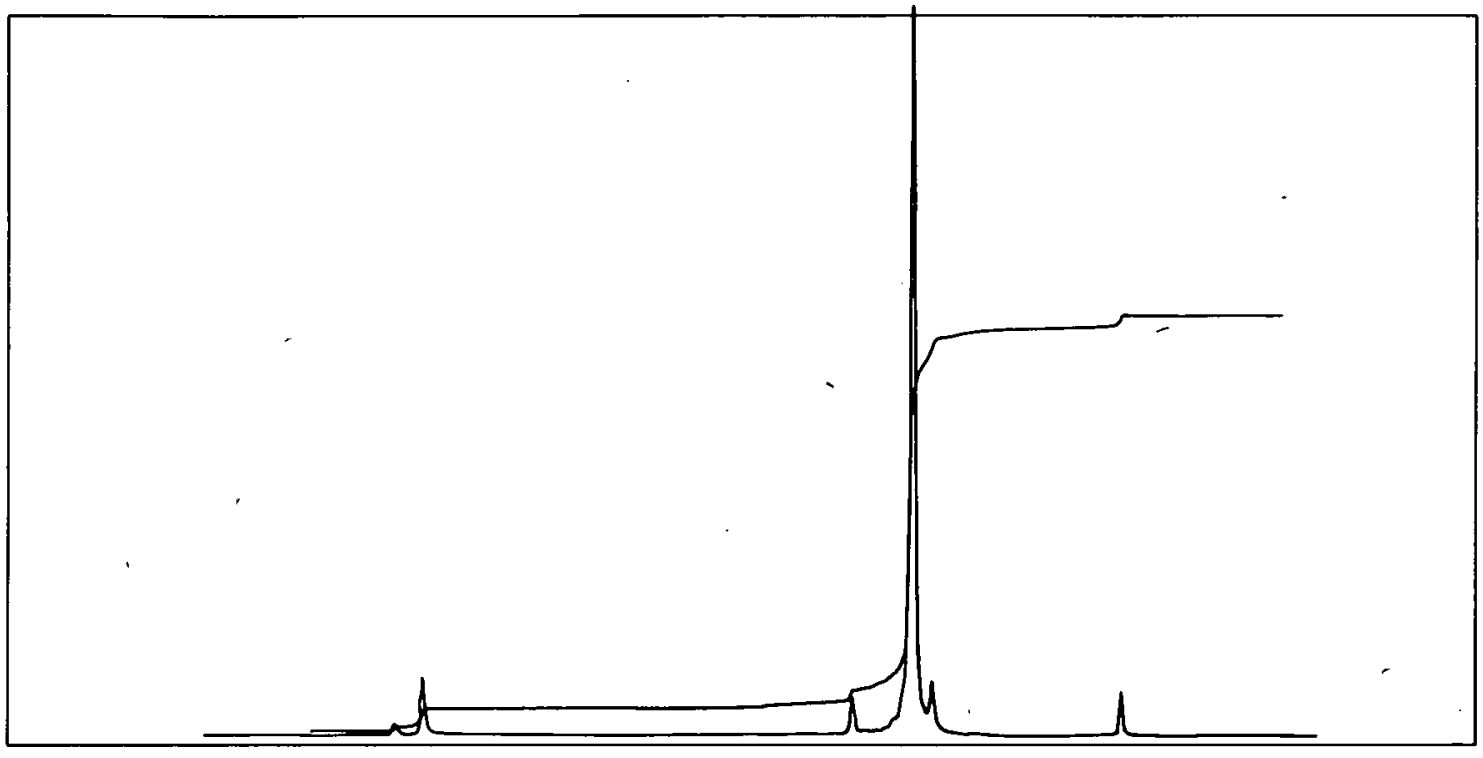

Figure A-5. FLUORINE MAGNETIC RESONANCE SPECTRUM OF THE HEXAFLUOROACETONE ADDUCT OF TRIETHANOLAMINE. (Sweep Width - $20 \mathrm{~Hz} / \mathrm{cm}$, Offset - $6600 \mathrm{~Hz}$ )

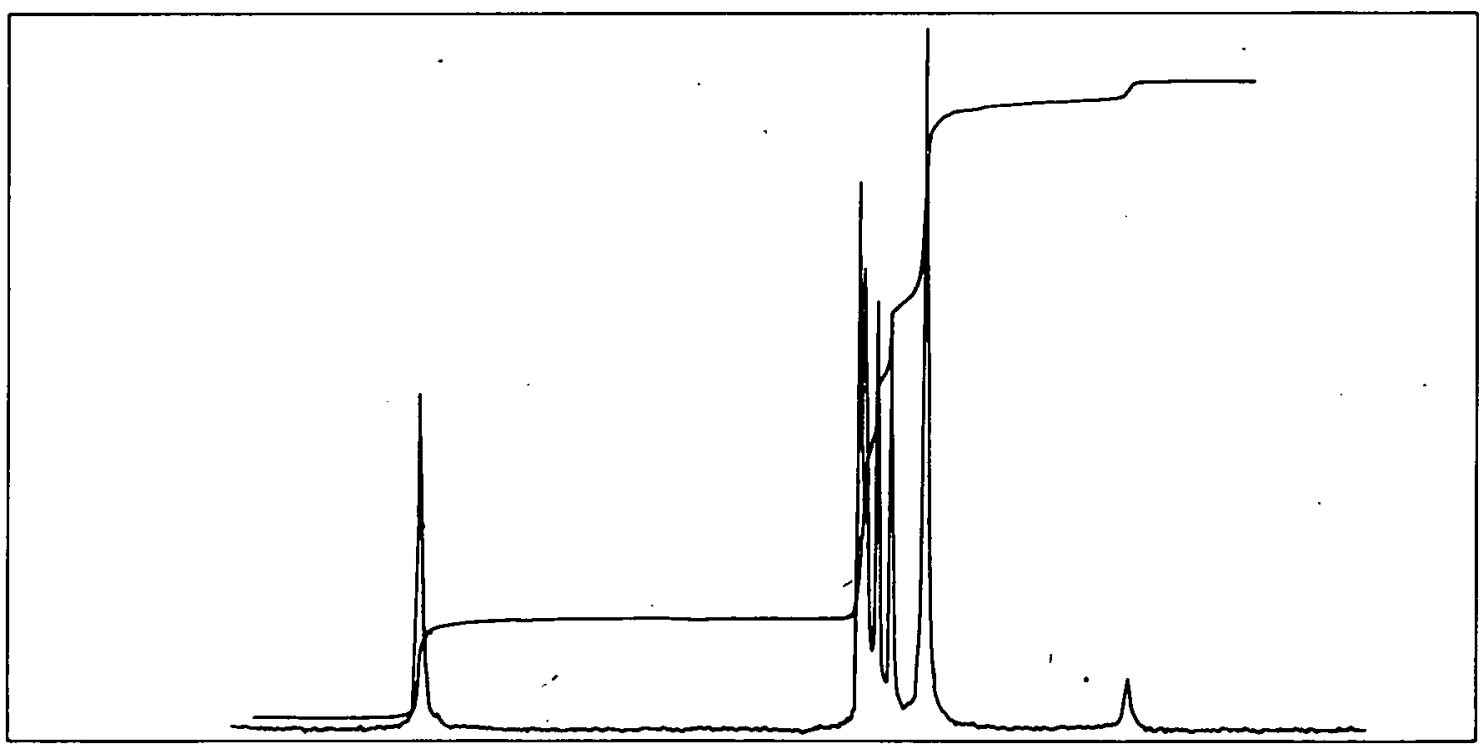

Figure A-6. FLUORINE MAGNETIC RESONANCE SPECTRUM OF 147.4 MILLIGRAMS OF DIETHANOLAMINE IN 0.5 MILLILITER OF 5\% HEXAFLUOROACETONE IN ETHYL ACETATE. In-Butyltrifluoroacetate - 75.9 Milligrams - was Added as a Standard and Hexafluorobenzene as the Internal Lock; Sweep Width $-20 \mathrm{~Hz} / \mathrm{cm}$, Offset - $6800 \mathrm{~Hz}$ ) 


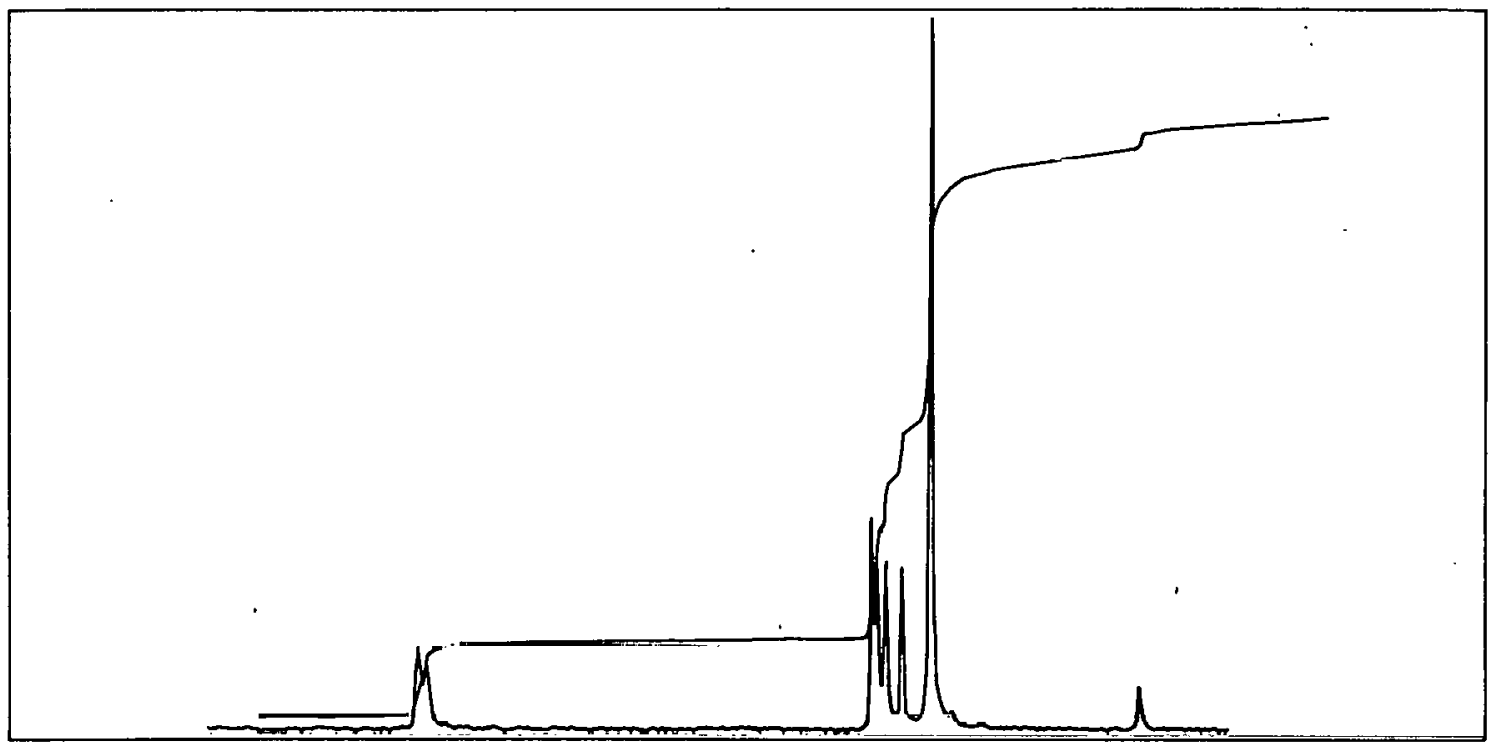

Figure A-7. FLUORINE MAGNETIC RESONANCE SPECTRUM OF 60.2 MILLIGRAMS OF TRIETHANOLAMINE, 83.4 MILLIGRAMS OF DIETHANOLAMINE, AND 60.3 MILLIGRAMS OF n-BUTYLTRIFLUOROACETATE IN 0.5 MILLILITER OF ETHYL ACETATE THROUGH WHICH HEXAFLUOROACETONE WAS BUBBLED FOR ONE MINUTE. (Sweep Width - $20 \mathrm{~Hz} / \mathrm{cm}$, Offset - $6600 \mathrm{~Hz}$ )

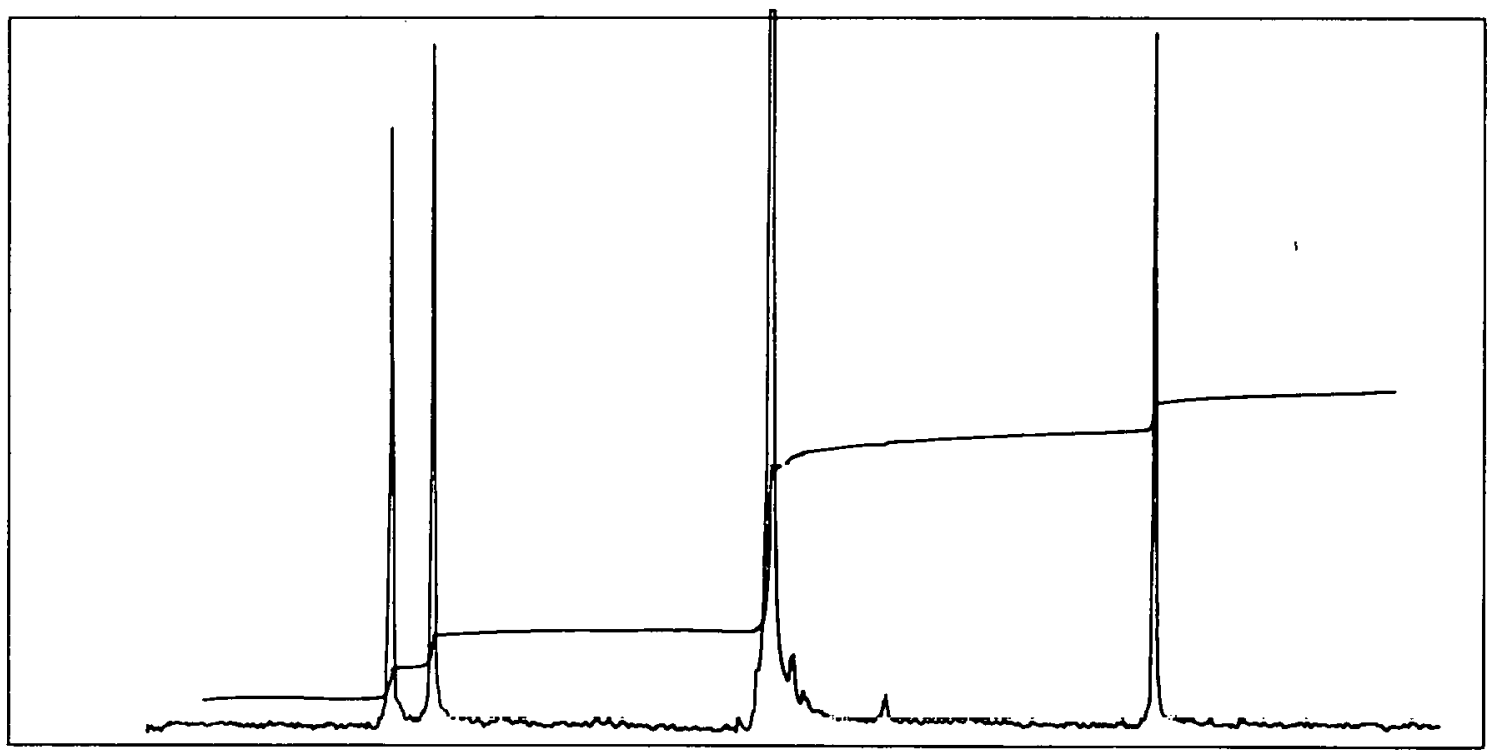

Figure A-8. FLUORINE MAGNETIC RESONANCE SPECTRUM OF 33.61 MILLIGRAMS OF n-BUTYLTRI. FLUOROACETATE AND 51.17 MILLIGRAMS OF METHYLENEDIANILINE IN 0.5 MILLILITER OF ETHYL ACETATE THROUGH WHICH HEXAFLUOROACETONE WAS BUBBLED FOR ONE MINUTE. (Sweep Width - 20 $\mathrm{Hz} / \mathrm{cm}$, Offset - $6600 \mathrm{~Hz}$ ) 


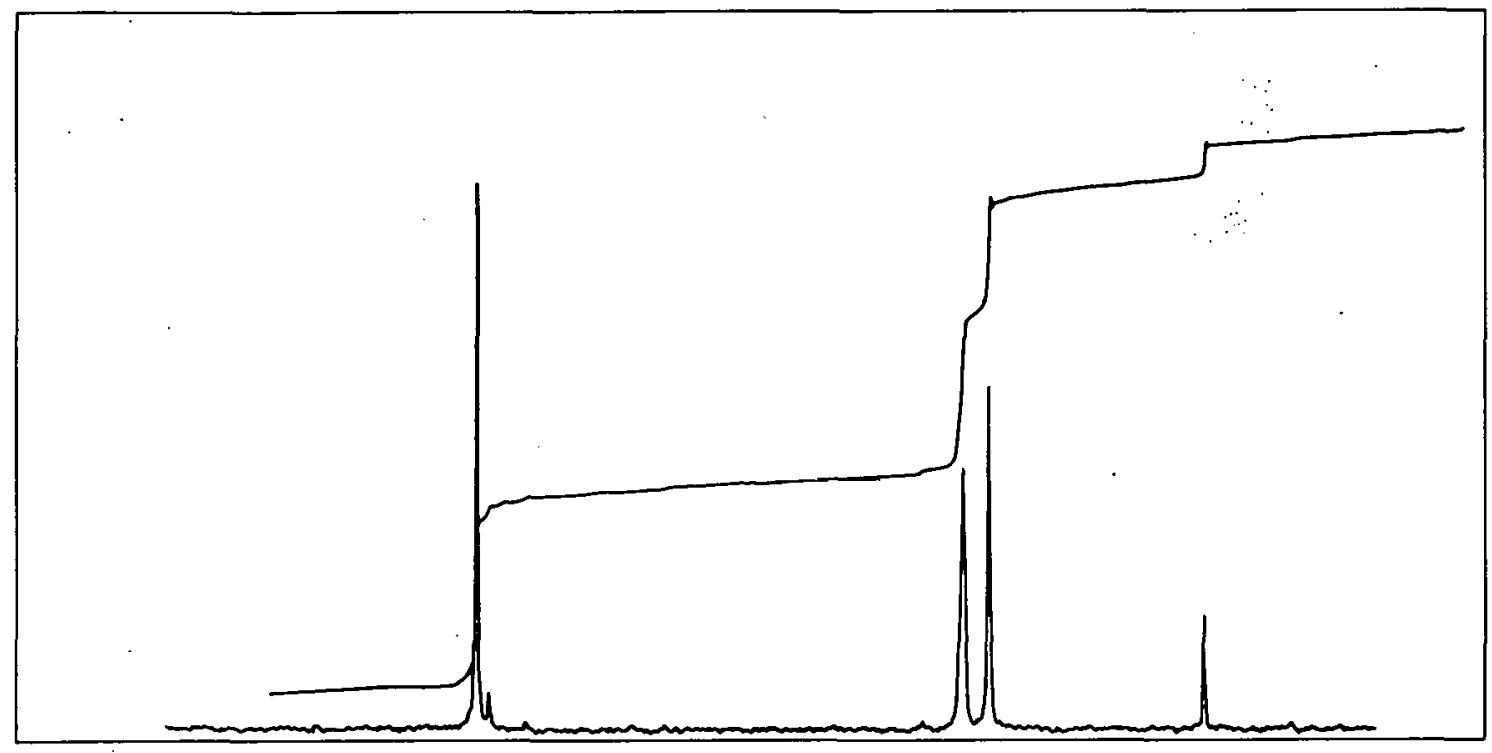

Figure A-9. FLUORINE MAGNETIC RESONANCE SPECTRUM OF HEXAFLUOROACETONE ADDUCT OF 86.82 MILLIGRAMS OF BISHYDROXYETHYLDIMERATE IN 0.5 MILLILITER OF BENZENE AND 45.04 MILLIGRAM OF n-BUTYLTRIFLUOROACETATE. (Sweep Width - $20 \mathrm{~Hz} / \mathrm{cm}$, Offset - $6600 \mathrm{~Hz}$ )

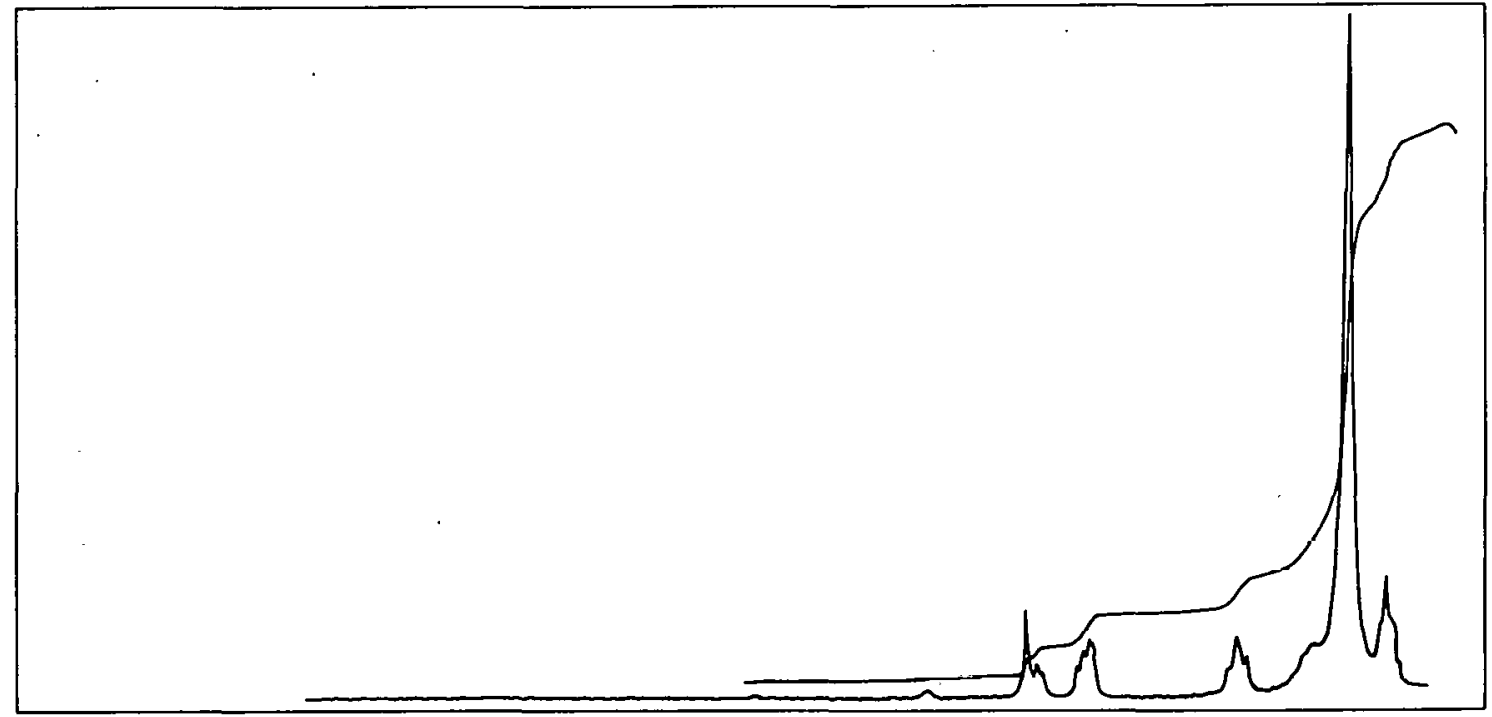

Figure A-10. PROTON MAGNETIC RESONANCE SPECTRUM OF BISHYDROXYETHYLDIMERATE. (SWeep Width - $20 \mathrm{~Hz} / \mathrm{em}$, Offset . Nono) 


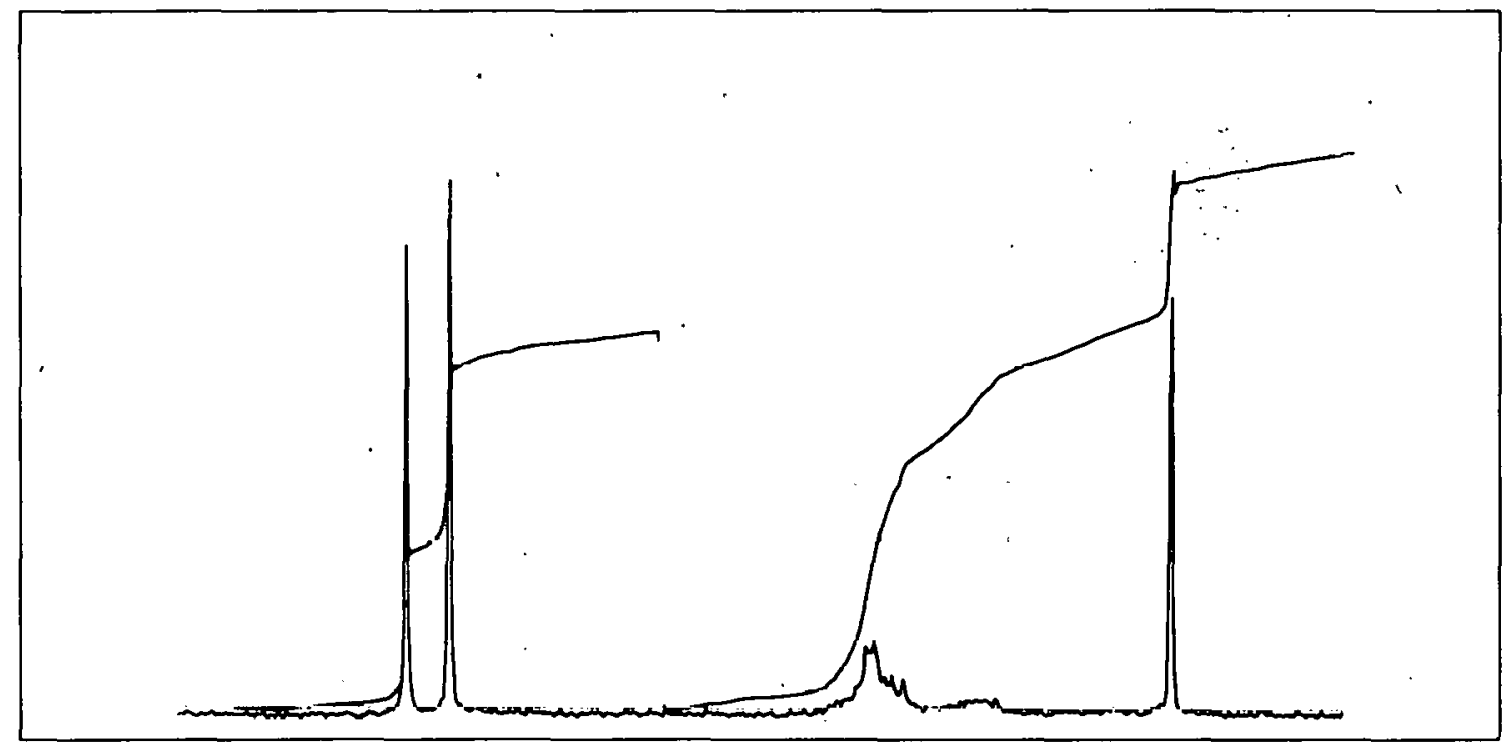

Figure A-11. FLUORINE MAGNETIC RESONANCE SPECTRUM OF HEXAFLUOROACETONE ADDUCT OF 83.94 MILLIGRAMS OF APOGEN AND 47.38 MILLIGRAMS OF n-BUTYLTRIFLUOROACETATE IN 0.5 MILLILITER OF ETHYL ACETATE. (Sweep Width - $20 \mathrm{~Hz} / \mathrm{cm}$, Offset - $6600 \mathrm{~Hz}$ )

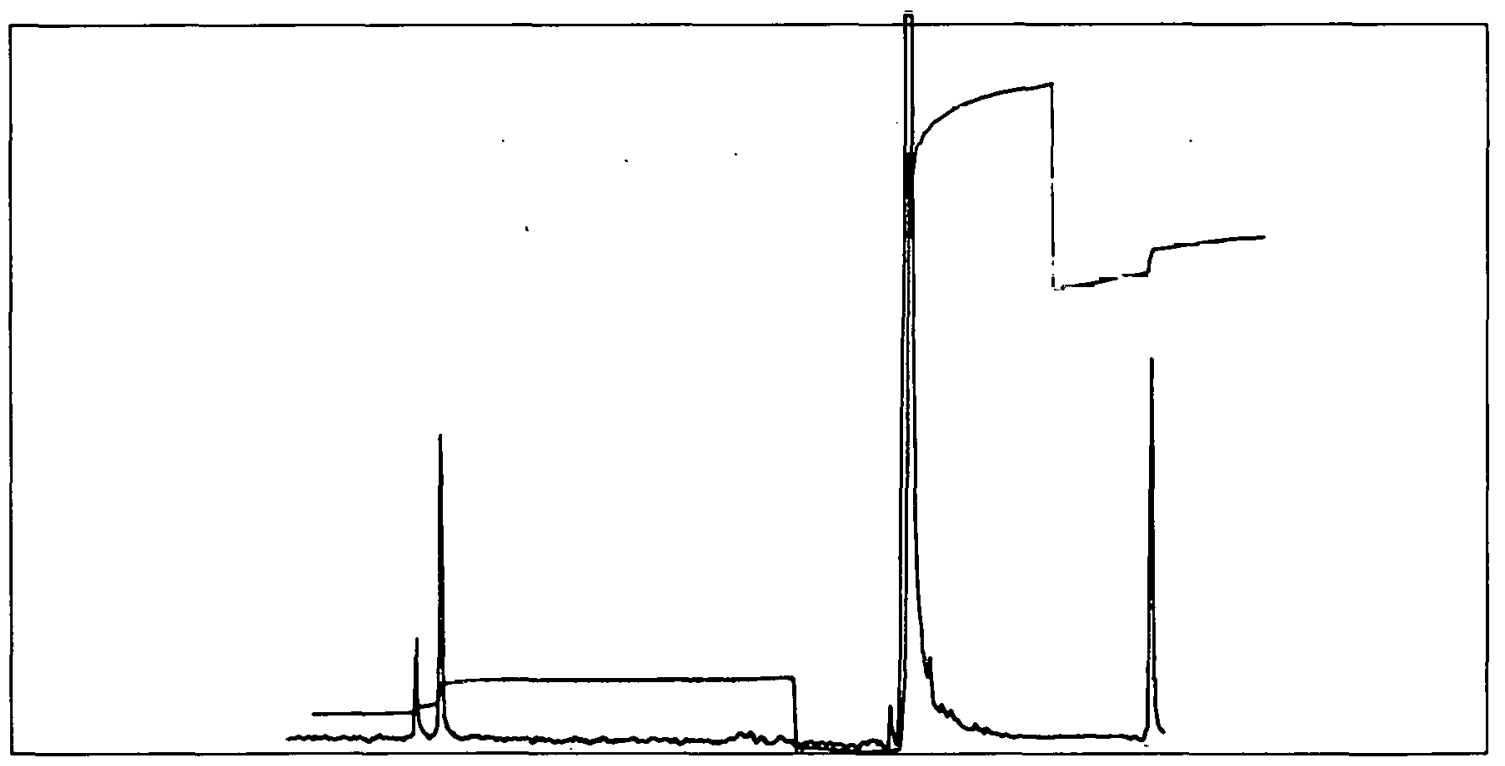

Figure A-12. FLUORINE MAGNETIC RESONANCE SPECTRUM OF HEXAFLUOROACETONE ADDUCT OF 113.75 MILLIGRAMS OF ETHYLENE GLYCOL AND 49.6 MILLIGRAMS OF n-BUTYLTRIFLUOROACETATE IN 0.5 MILLILITER OF ETHYLACETATE. (Sweep Width - $20 \mathrm{~Hz} / \mathrm{cm}$, Offset - $6600 \mathrm{~Hz}$ ) 


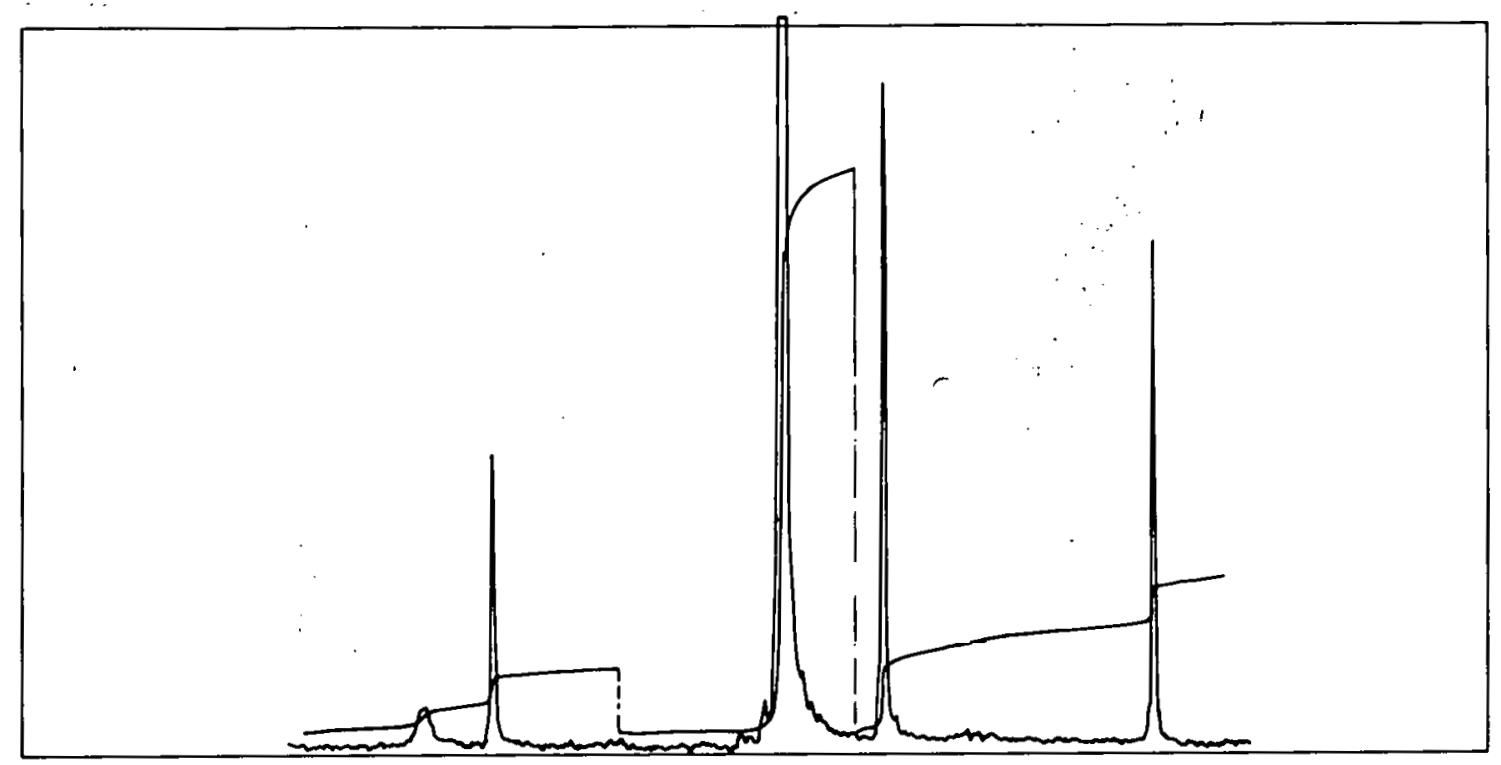

Figure A-13. FLUORINE MAGNETIC RESONANCE SPECTRUM OF HEXAFLUOROACETONE ADDUCT OF 92.9 MILLIGRAMS OF ETHYLENEDIAMINE AND 48.95 MILLIGRAMS OF n-BUTYLTRIFLUOROACETATE IN 0.5 MILLILITER OF ETHYL ACETATE. (Sweep Width $-20 \mathrm{~Hz} / \mathrm{cm}$, Offset - $6600 \mathrm{~Hz}$ )

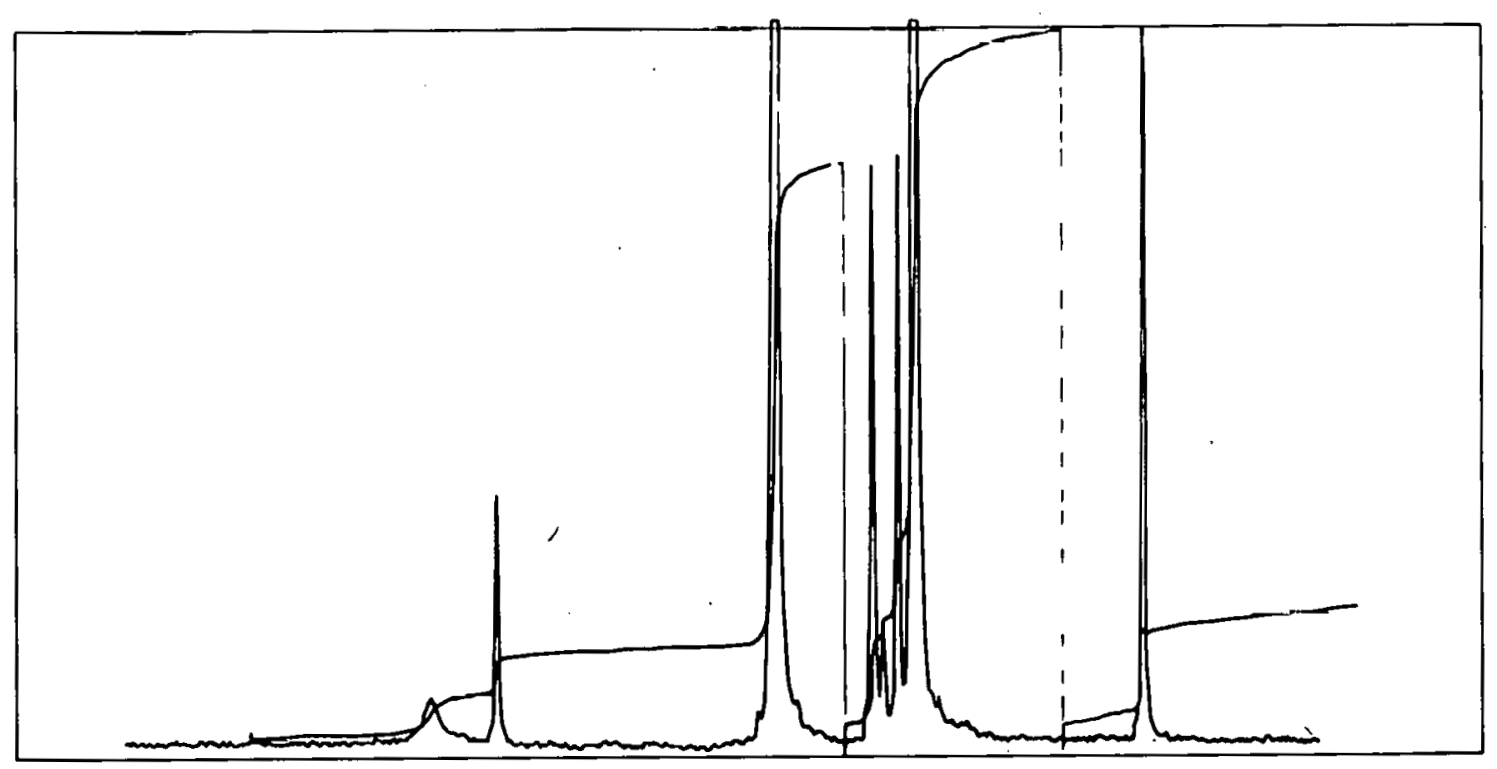

Figure A-14. FLUORINE MAGNETIC RESONANCE SPECTRUM OF HEXAFLUOROACETONE ADDUCT OF 135.85 MILLIGRAMS OF 2-AMINOETHANOL AND 47.45 MILLIGRAMS OF n-BUTYLTRIFLUOROACETATE IN 0.5 MILLILITER OF ETHYL ACETATE. (Sweep Width - $20 \mathrm{~Hz} / \mathrm{cm}$, Offset $-6600 \mathrm{~Hz}$ ) 


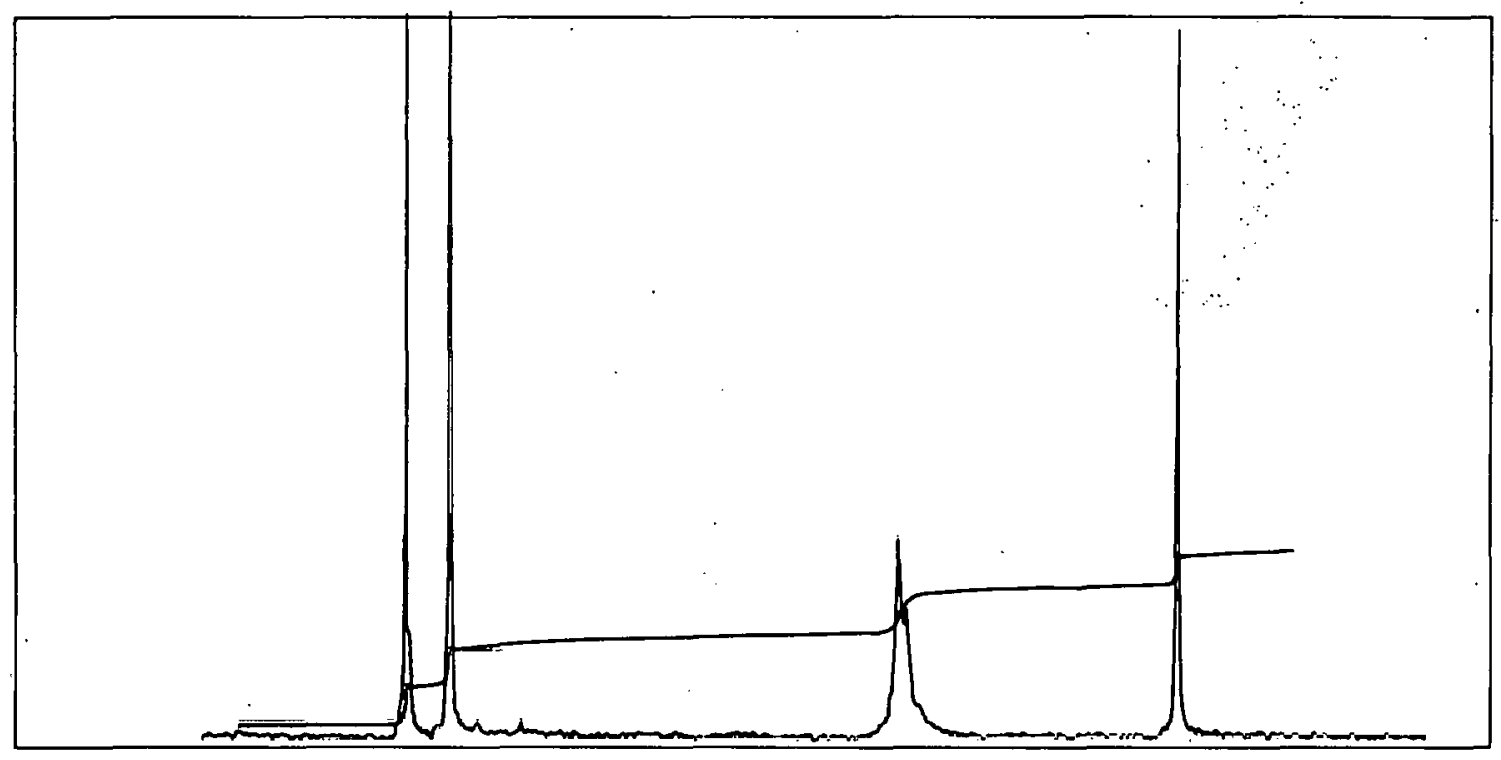

Figure A-15. FLUORINE MAGNETIC RESONANCE SPECTRUM OF HEXAFLUOROACETONE ADDUCT OF 100.44 MILLIGRAMS OF. DYNACHEM AND 40.83 MILLIGRAMS OF n-BUTYLTRIFLUOROACETATE IN 0.5 MILLILITER OF ETHYL ACETATE. (Sweep Width $-20 \mathrm{~Hz} / \mathrm{cm}$, Offset - $6600 \mathrm{~Hz}$ )

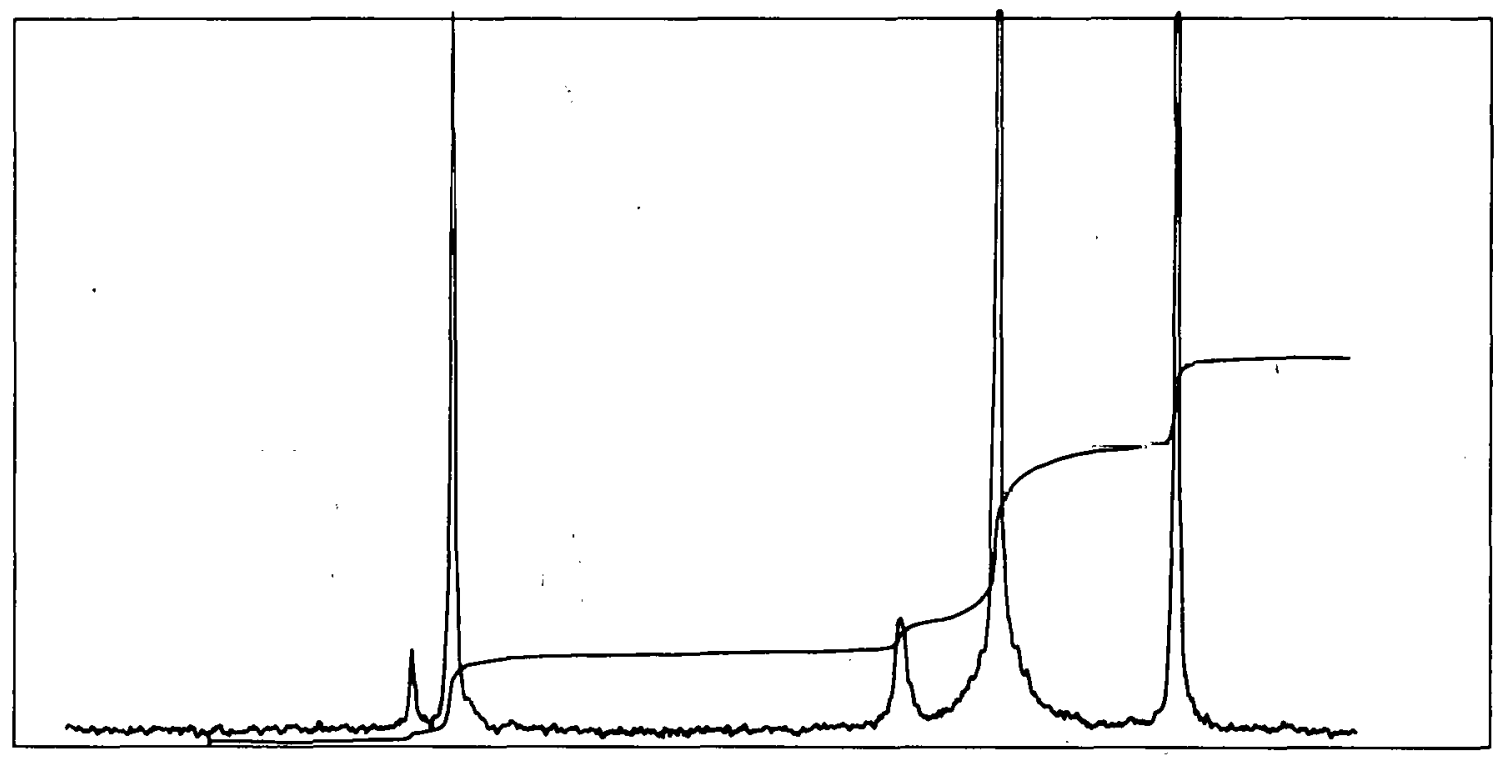

Figure A-16. FLUORINE MAGNETIC RESONANCE SPECTRUM OF HEXAFLUOROACETONE ADDUCT OF 108.55 MILLIGRAMS OF EPON 1001 AND 56.3 MILLIGRAMS OF n-BUTYLTRIFLUOROACETATE IN 0.5 MILLILITER OF ETHYL ACETATE. (Sweep Width - $20 \mathrm{~Hz} / \mathrm{cm}$, Offset - $6600 \mathrm{~Hz}$ ) 


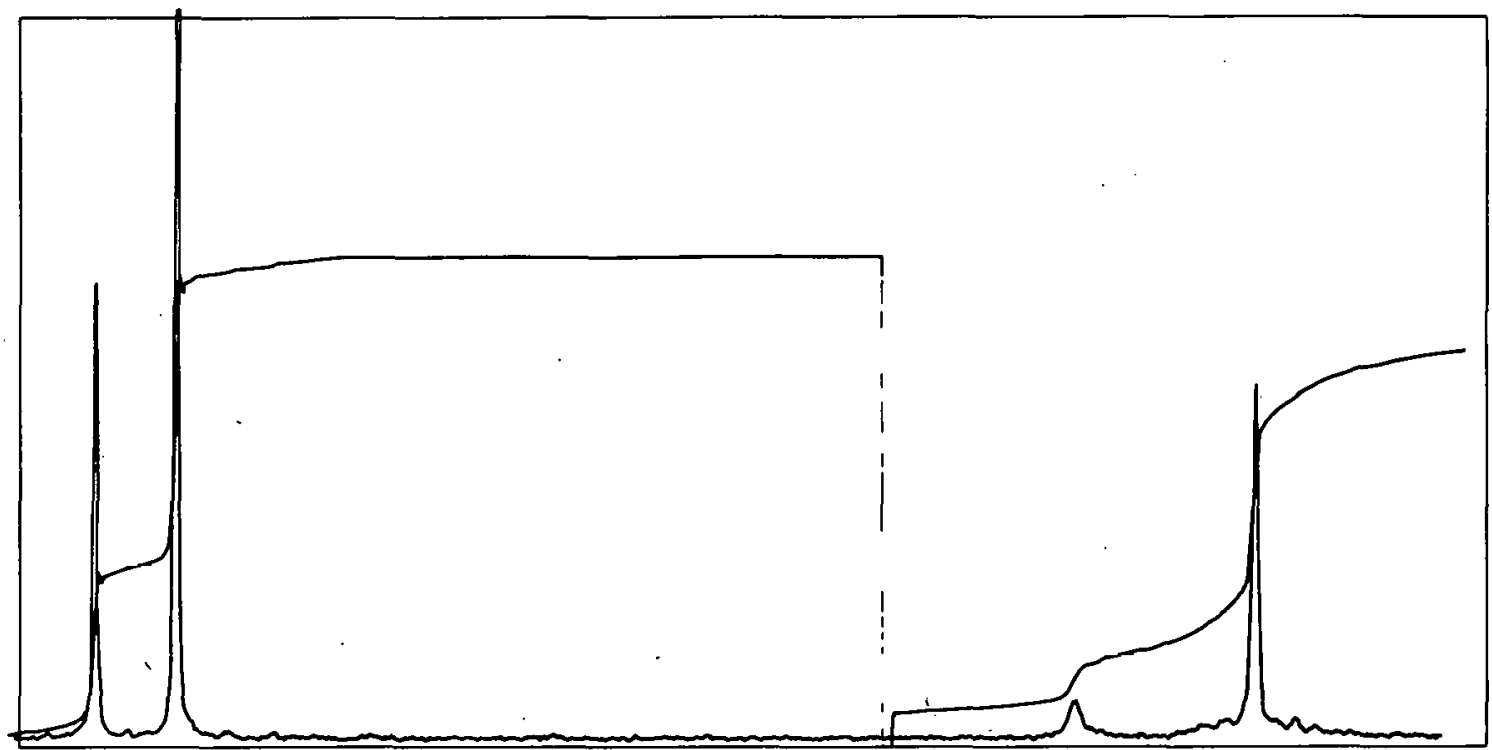

Figure A-17. EXPANDED FLUORINE MAGNETIC RESONANCE SPECTRUM OF HEXAFLUOROACETONE ADDUCT OF 94.75 MILLIGRAMS OF EPON 1001 AND 100 MILLIGRAMS OF n-BUTYLTRIFLUOROACETATE IN 0.5 MILLILITER OF ETHYL ACETATE. (Sweep Width $-10 \mathrm{~Hz} / \mathrm{cm}$, Offset $-6920^{-} \mathrm{Hz}$ )

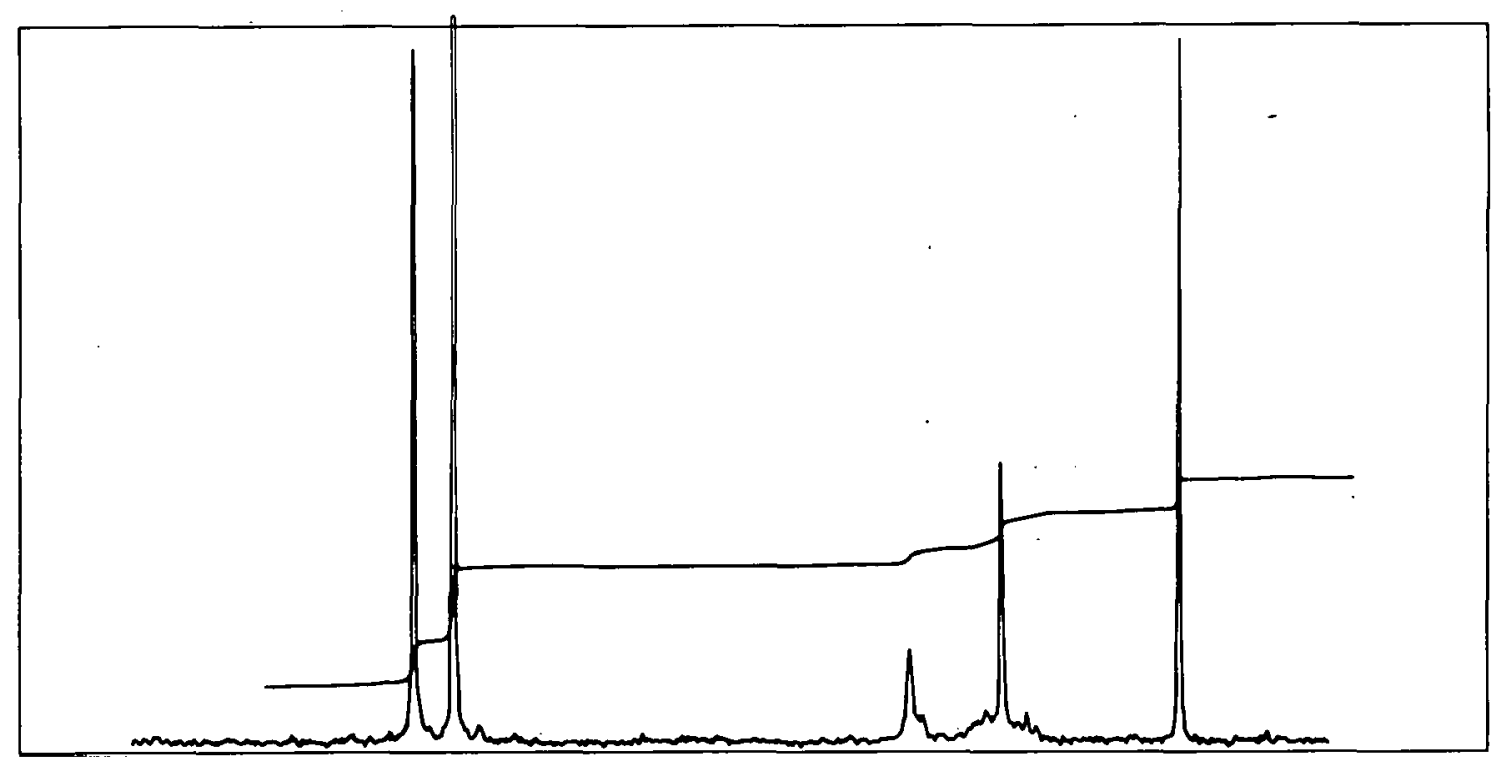

Figure A-18. 'FLUORINE MAGNETIC RESONANCE SPECTRUM OF HEXAFLUOROACETONE ADDUCT OF 192.95 MILLIGRAMS OF EPON 828 AND $56: 7$ MILLIGRAMS OF n-BUTYLTRIFLUOROACETATE IN 0.5 MILLILITER OF FTHYI ACETATE. (Sweep Width $-20 \mathrm{~Hz} / \mathrm{cm}$. Offset - $6600 \overline{0} \mathrm{~Hz}$ ) 


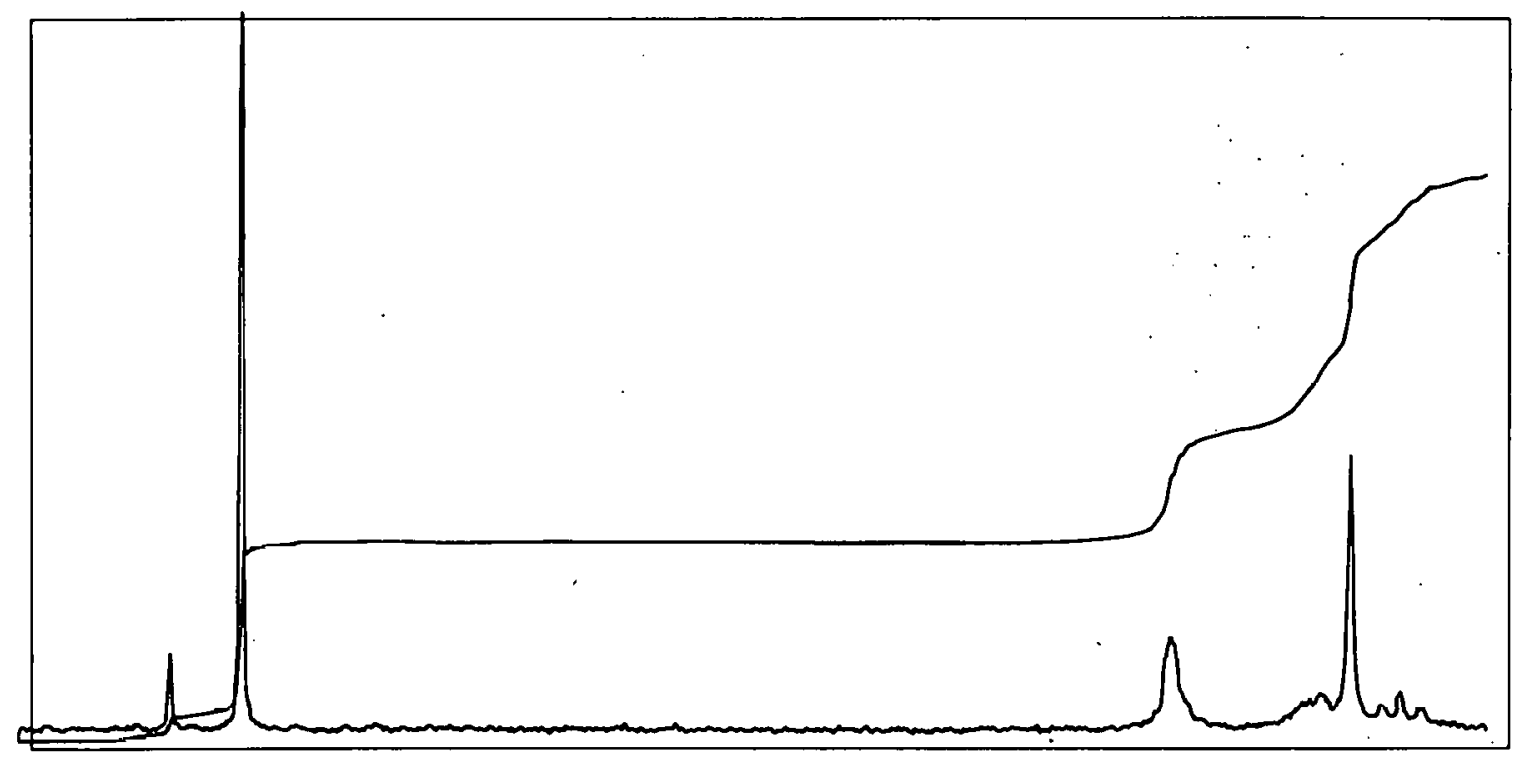

Figure A-19. EXPANDED FLUORINE MAGNETIC RESONANCE SPECTRUM OF HEXAFLUOROACETONE ADDUCT OF 382.85 MILLIGRAMS OF EPON 828 AND 50 MILLIGRAMS OF $n$-BUTYLTRIFLUOROACETATE IN 1 MILLILITER OF ETHYL ACETATE. (Sweep Width $-10 \mathrm{~Hz} / \mathrm{cm}, 0 \mathrm{ff} 6 \theta \mathrm{t}-6920 \mathrm{~Hz}$ )

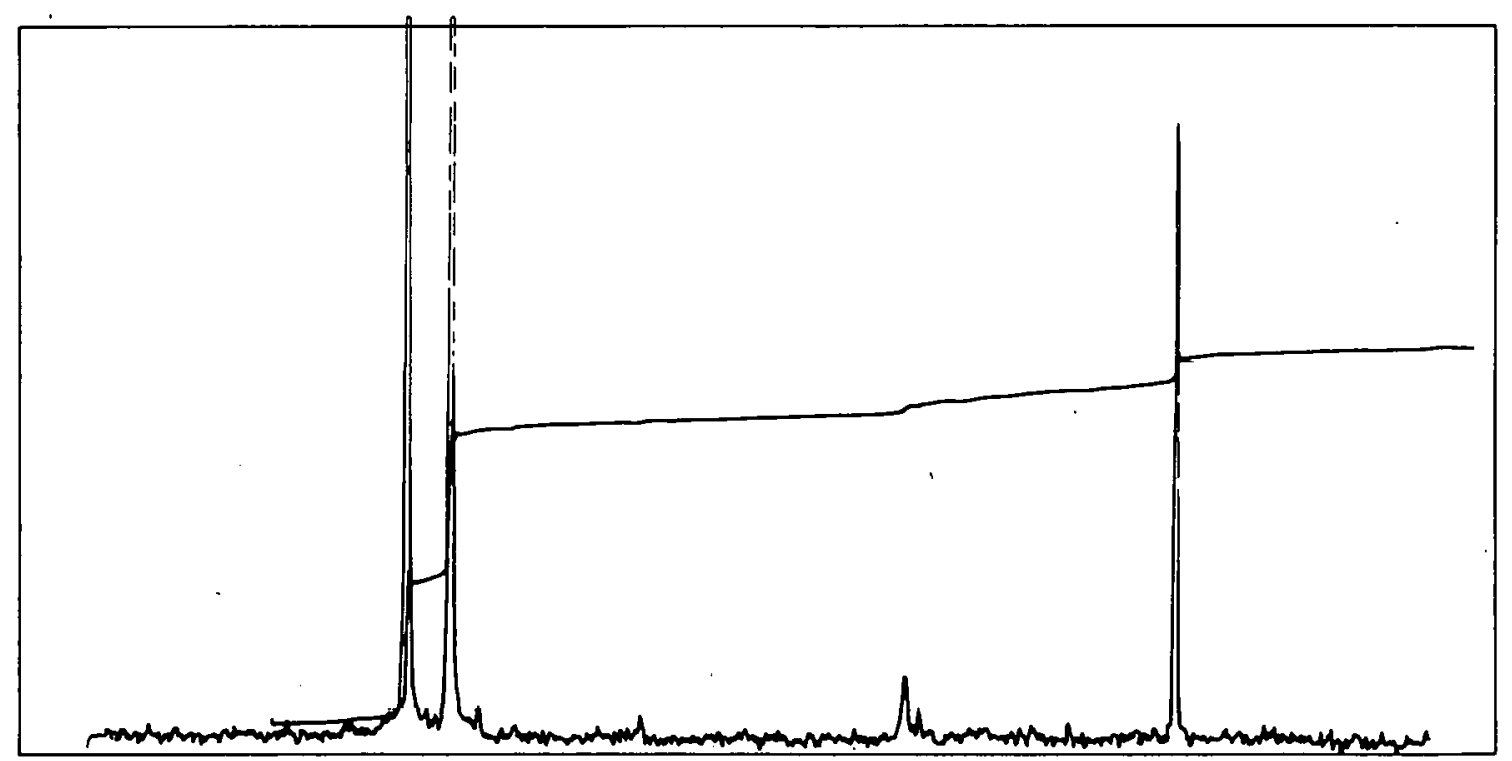

Figure A-20. FLUORINE MAGNETIC RESONANCE SPECTRUM OF HEXAFLUOROACETONE ADDUCT OF 112.6 MILLIGRAMS OF EPI-REZ 508 AND 55.7 MILLIGRAMS OF n-BUTYLTRIFLUOROACETATE IN 0.5 MILLILITER OF ETHYL ACETATE. (Sweep Width - $20 \mathrm{~Hz} / \mathrm{cm}$, Offset $\cdot 6600 \mathrm{~Hz}$ ) 


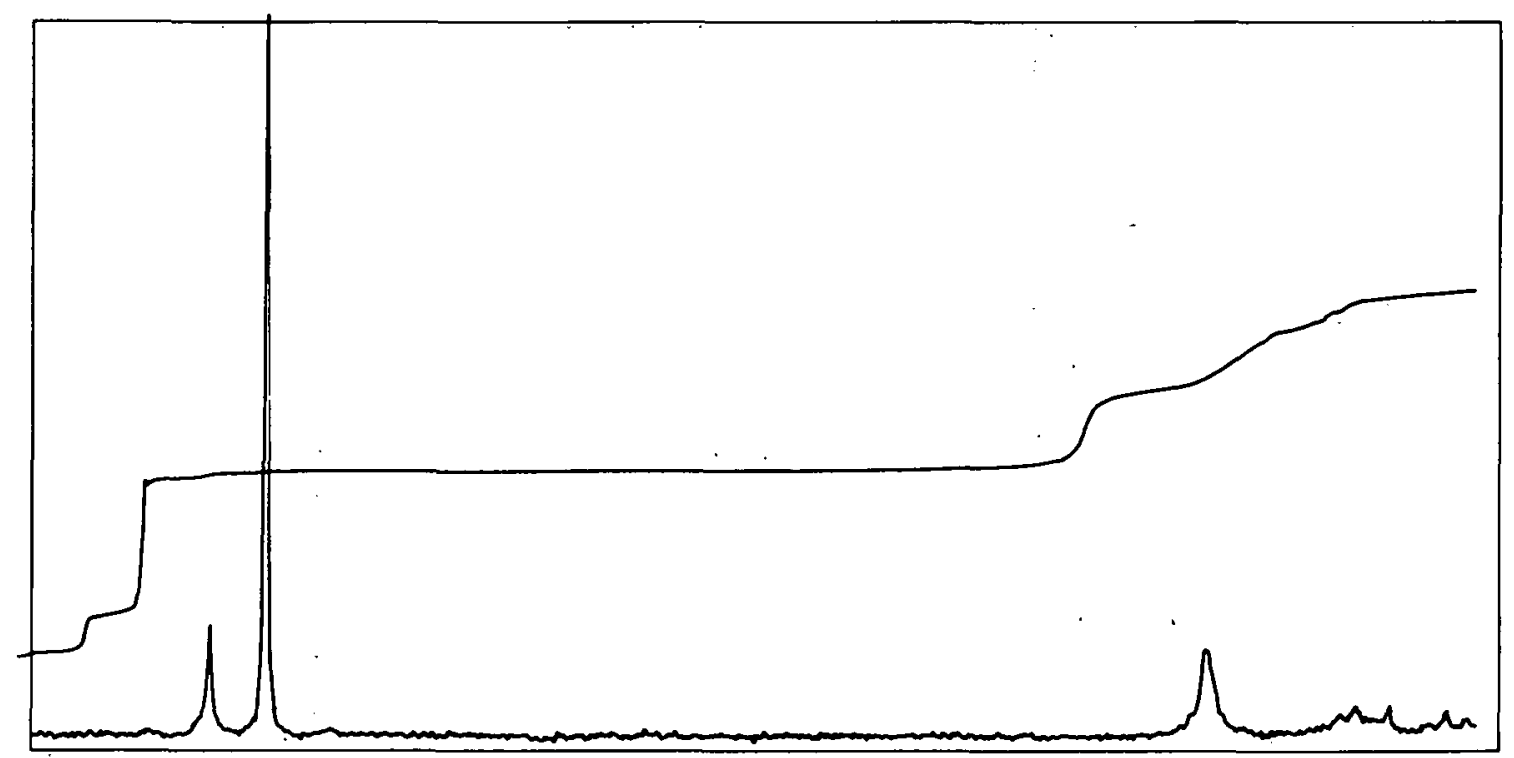

Figure A-21. EXPANDED FLUORINE MAGNETIC RESONANCE SPECTRUM OF HEXAFLUOROACETONE ADDUCT OF 654 MILLIGRAMS OF EPI-REZ 508 AND 50 MILLIGRAMS OF $n$-BUTYLTRIFLUOROACETATE IN 0.5 MILLILITER OF ETHYL ACETATE. (Sweep Width - $10 \mathrm{~Hz} / \mathrm{cm}$, Offset - 6920.'Hz, Integral Offset $-6970 \mathrm{~Hz}$ )

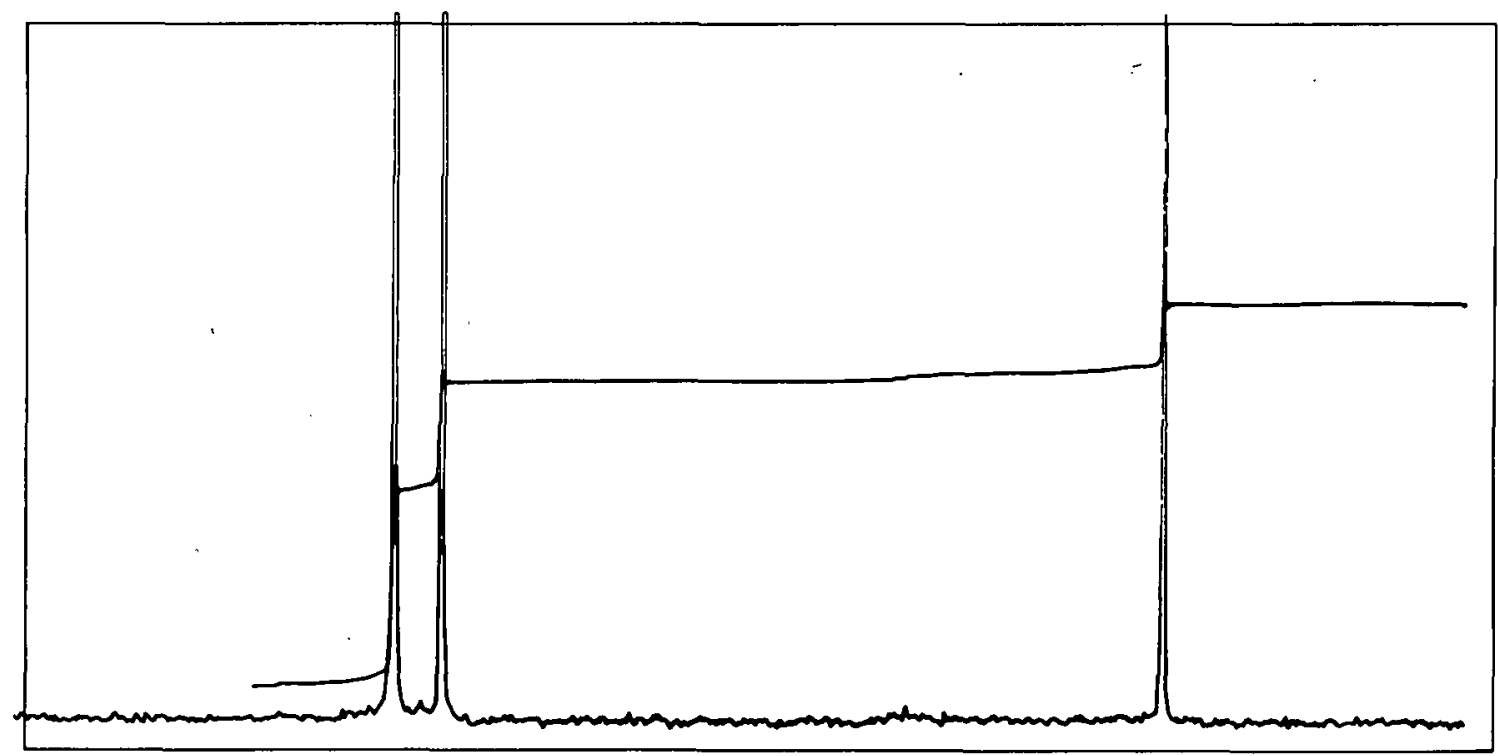

Figure A-22. FLUORINE MAGNETIC RESONANCE SPECTRUM OF HEXAFLUOROACETONE ADDUCT OF 149.55 MILLIGRAMS OF 1, 2, 7, 8-DIEPOXYOCTANE AND 55 MILLIGRAMS OF n-BUTYLTRIFLUOROACETATE IN 0.5 MILLILITER OF ETHYL ACETATE. (Swëép Widtlı - $20 \mathrm{~Hz} / \mathrm{cm}$, OIfsü - $6800 \mathrm{H}_{2}$ ) 


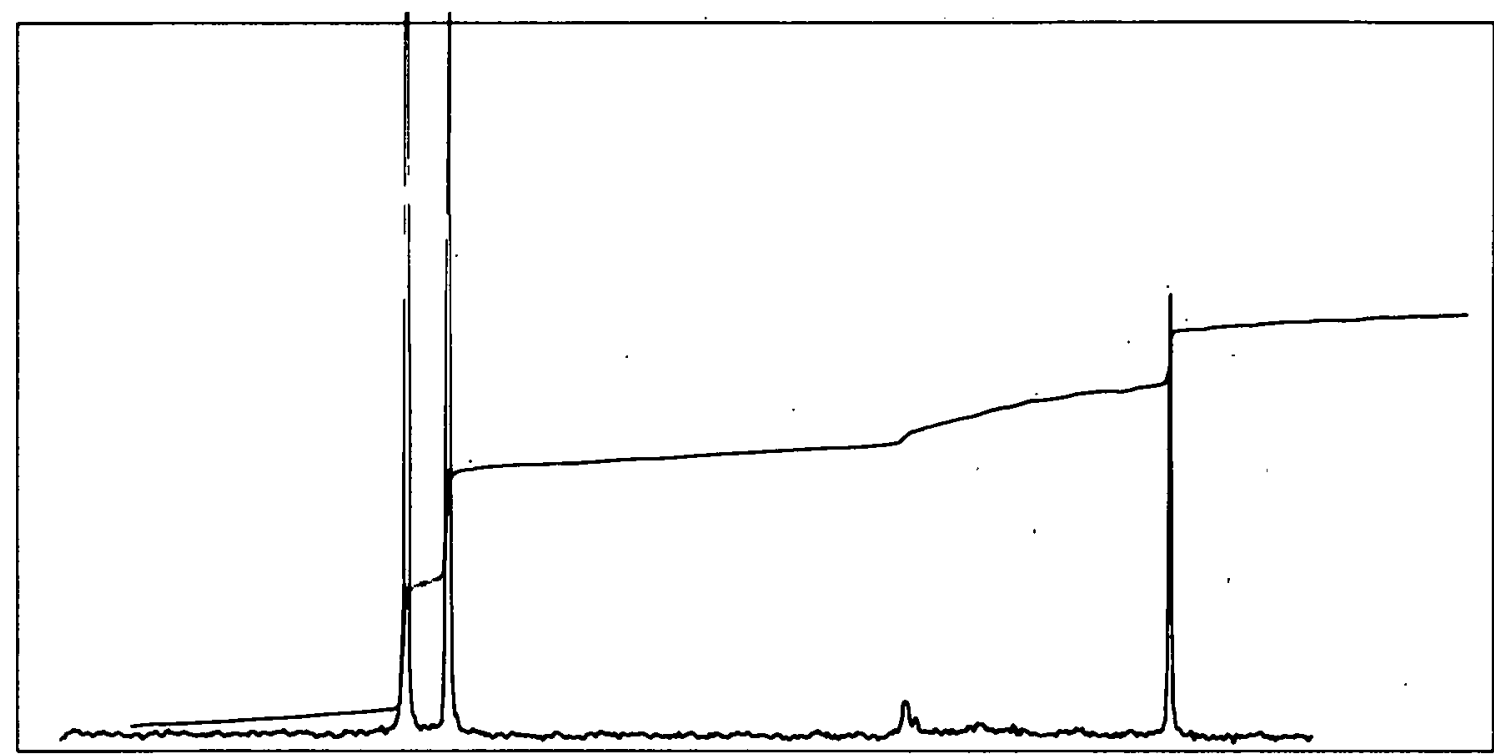

Figure A-23. FLUORINE MAGNETIC RESONANCE SPECTRUM OF HEXAFLUOROACETONE ADDUCT OF 186.4 MILLIGRAMS OF PHENYLGLYCIDYL ETHER AND 55 MILLIGRAMS OF $\underline{n}$-BUTYLTRIFLUOROACETATE IN 0.5 MILLILITER OF ETHYL ACETATE. (Sweep Width - $20 \mathrm{~Hz} / \mathrm{cm}$, Offset $-6600 \mathrm{~Hz}$ )

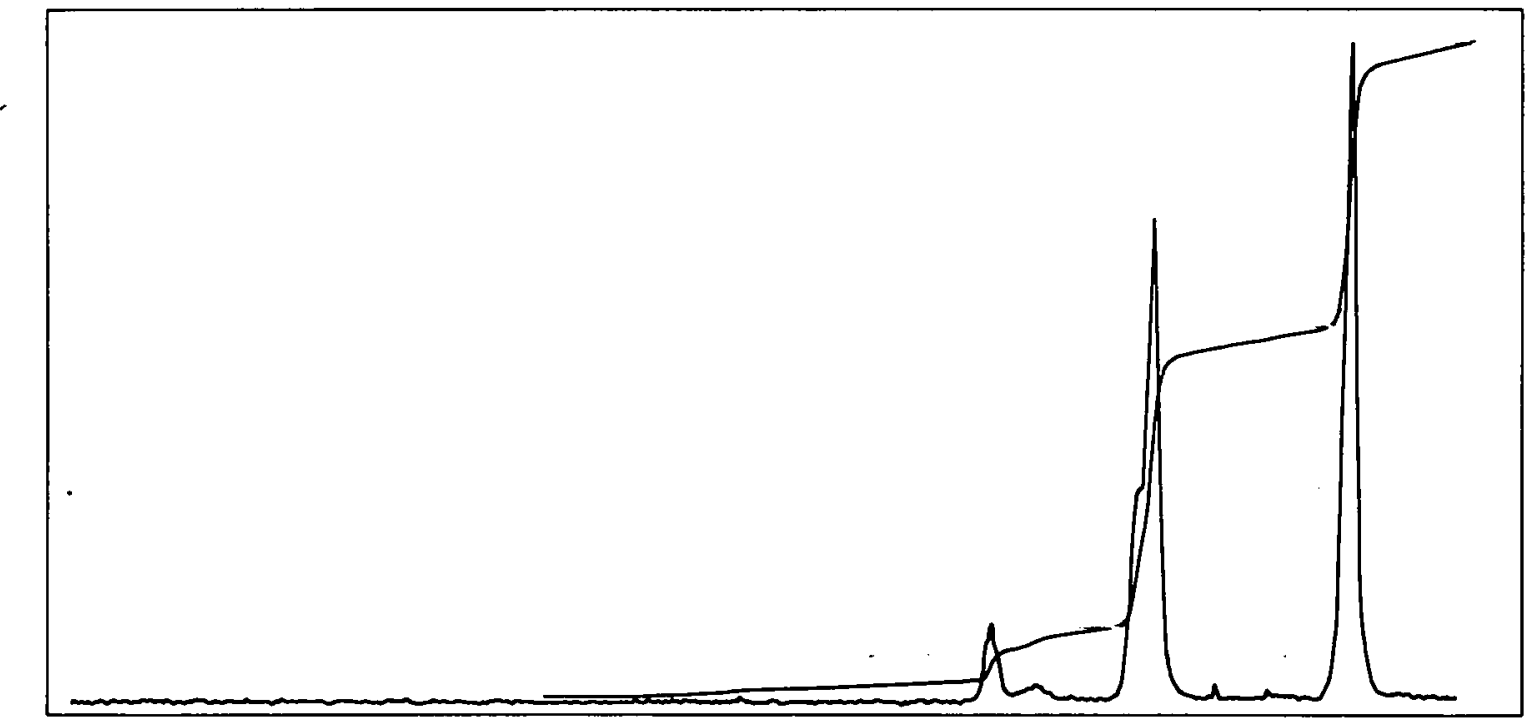

Figure A-24. PROTON MAGNETIC RESONANCE SPECTRUM OF URALITE 3121S, PART B, IN CARBON TETRACHLORIDE. (Sweep Width - $20 \mathrm{~Hz} / \mathrm{cm}$, Offset - None) 


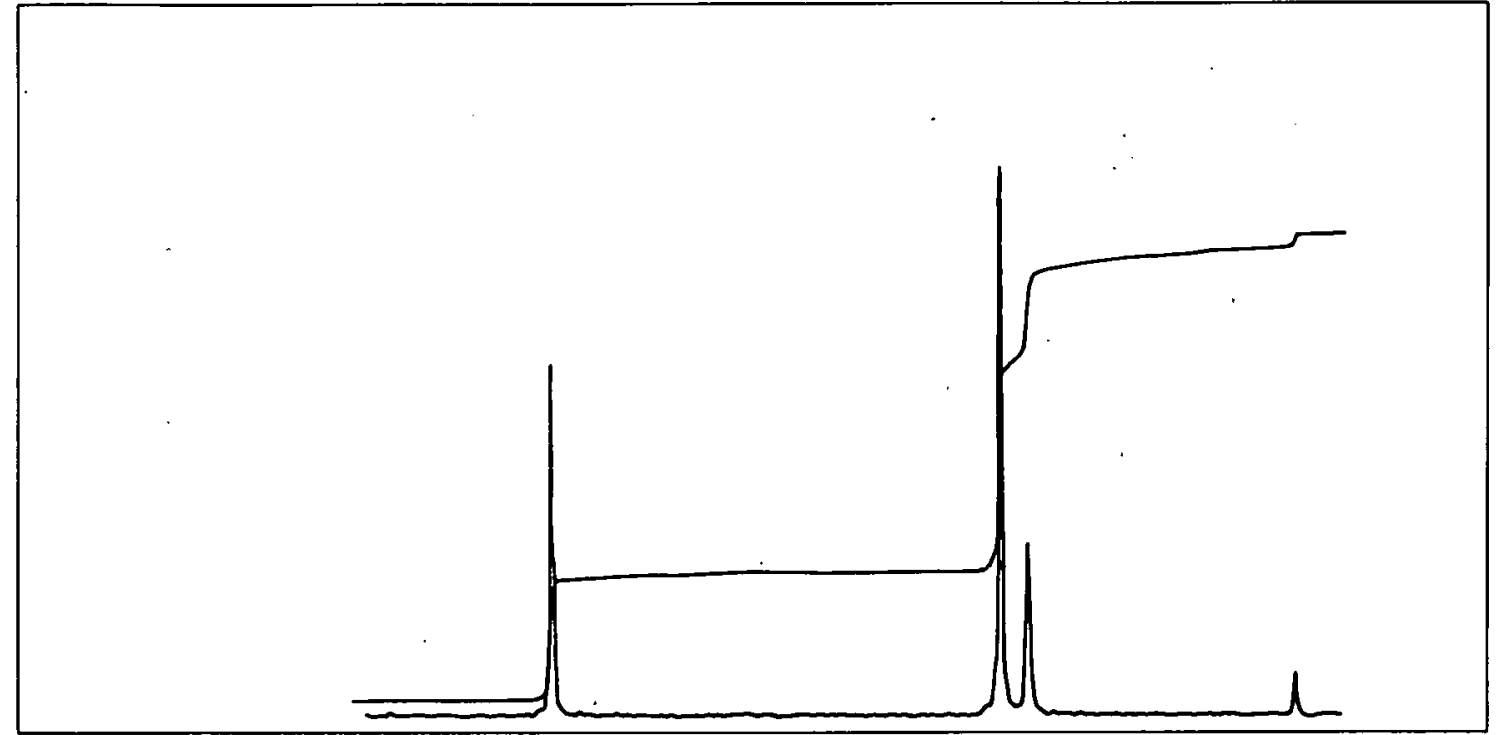

Figure A-25. FLUORINE MAGNETIC RESONANCE SPECTRUM OF HEXAFLUOROACETONE ADDUCT OF 134.65 MILLIGRAMS OF URALITE 3121S, PART B, AND 110 MILLIGRAMS OF -BUTYLTRIFLUOROACETATE IN CARBON TETRACHLORIDE. (Sweep Width - $20 \mathrm{~Hz} / \mathrm{cm}$, Offset - $6600 \mathrm{~Hz}$ ) 


\section{Distribution}

Energy Research and Development Administration - Oak Ridge

Hickman, H. D.

Leed, R. E.

Zachry, D. S., Jr

Technical Information Center (2)

Holifield National Laboratory

Benjamin, B. M.

Brown, L. L.

Carter, J. A.

Singer, G. M.

\section{Oak Ridge Gaseous Diffusion Plant}

Barton, J. C.

Evans, E. C.

Stewart, J. H.

Weber, C. W.

Wilcox, W. J., Jr

Winkel, R. A.

Oak Ridge Y-12 Plant

Bernander, N. $K$.

Briscoe, O. W.

Burditt, R. B.

Bựrkliạiț. L. E,

Dorsey, G. F.

Dorsey, J. G. (25)

Eager, M. H. (5)

Fraser, R. J.

Gambill, E. F.

Green, L. ^. (Б)

Green, R. C.

Harper, W. L.

Harman, W. D.

Jackson, V. C.

Jones, F. W.

Kahl, K. G.

Keith, $A$.
Kite, H. T.

Lang, D. M.

Lundin, M. I.

Marrow, G. B.

McCauley, L. L.

McLendon, J. D.

Mills, J. M., Jr

Perry, A. E.

Phillips, L. R.

Rowan, .J. H.

Rutenberg, A. C. (5)

Schmitt. C. R.

Schreyer, J. M.

Smith, H. F., Jr

Smith, R. D.

Smith, W. E.

Stephens, L. A.

Tewes, W. E.

Thomason, J. C.

Trammel, H. E.

Weathersby, W. E.

Whitehead, H. D.

Williams, R. D.

Yaggi, W. J./Googin, J. M.

$Y-12$ Central Files (5)

$Y-12$ Central Files (master copy)

$Y-1 \%$ Gentral Files (route cony).

$Y$-12 Central Files (Y-12RC)

Zerby, C. D.

Paducah Gaseous Diffusion Plant L'evin, 'R. W.

In addition, this report is distributed in accordance with the category UC-4, Chemistry, as given in the USERDA Standard Distribution Lists for Unclassified Scientific and Technical Reports, TID-4500. 